\title{
State of The Art Review of Cell Therapy in the Treatment of Lung Disease, and The Potential for Aerosol Delivery
}

\author{
Hosanna Brave ${ }^{1}$ and Ronan MacLoughlin $2,3,4, *$ (D) \\ 1 College of Medicine, Nursing \& Health Sciences, National University of Ireland, H91 TK33 Galway, Ireland; \\ h.brave1@nuigalway.ie \\ 2 Department of Chemistry, Royal College of Surgeons in Ireland, D02 YN77 Dublin, Ireland \\ 3 School of Pharmacy and Pharmaceutical Sciences, Trinity College, D02 PN40 Dublin, Ireland \\ 4 Aerogen Ltd. Galway Business Park, H91 HE94 Galway, Ireland \\ * Correspondence: rmacloughlin@aerogen.com; Tel.: +353-91540400
}

Received: 14 August 2020; Accepted: 31 August 2020; Published: 3 September 2020

\begin{abstract}
Respiratory and pulmonary diseases are among The leading causes of death globally. Despite tremendous advancements, there are no effective pharmacological therapies capable of curing diseases such as COPD (chronic obstructive pulmonary disease), ARDS (acute respiratory distress syndrome), and COVID-19. Novel and innovative therapies such as advanced therapy medicinal products (ATMPs) are still in early development. However, they have exhibited significant potential preclinically and clinically. There are several longitudinal studies published, primarily focusing on the use of cell therapies for respiratory diseases due to their anti-inflammatory and reparative properties, thereby hinting that they have The capability of reducing mortality and improving the quality of life for patients. The primary objective of this paper is to set out a state of The art review on The use of aerosolized MSCs and their potential to treat these incurable diseases. This review will examine selected respiratory and pulmonary diseases, present an overview of The therapeutic potential of cell therapy and finally provide insight into potential routes of administration, with a focus on aerosol-mediated ATMP delivery.
\end{abstract}

Keywords: mesenchymal stem cell; conditioned media; aerosol; respiratory; ATMP; exosomes; secretome; lung; nebulizer

\section{Introduction}

Advanced therapy medicinal products (ATMPs) are biological therapeutics primarily used for humans and animals. ATMPs can be classified into four types: gene therapy, somatic cell therapy, tissue-engineered products, or a combination of all three [1]. ATMPs are researched and developed in hospitals, academia, and small-sized enterprises [2]. Large pharmaceutical companies are not involved in The development and manufacturing of ATMPs since ATMPs are not of great interest to them [3]. Many of these ATMPs are still in The developmental stages [4]. ATMPs are said to bring about better health benefits, which include treatments for untreatable diseases and prevalent conditions $[5,6]$. There are a limited number of ATMPs that The European Medicines Agency (EMA) has approved (see Figure 1). Moreover, there are a profound amount of ATMPs being developed clinically. Plus, the number of ATMPs that are approved and licensed increases every year. Regulatory bodies such as The EMA give a positive and expert opinion on developed ATMPs which are then subsequently authorized by The European Commission (EC) [7]. Some ATMPs that have been approved and authorized include: Strimvelis ${ }^{\circledR}$, Yescarta ${ }^{\circledR}$, Imlygic ${ }^{\circledR}$, Kymriah $^{\circledR}$, Luxturna ${ }^{\circledR}$, and Zolgensma ${ }^{\circledR}$ which are gene therapy medicinal products; somatic cell therapy products, Zalmoxis ${ }^{\circledR}$, Alofisel ${ }^{\circledR}$, 
and KTE-X19 ${ }^{\circledR} ;$ Holoclar ${ }^{\circledR}$ and Spherox ${ }^{\circledR}$, tissue-engineered products (see Figure 1). This present review will focus on cell therapies and their potential in treating various pulmonary and respiratory diseases and infections.

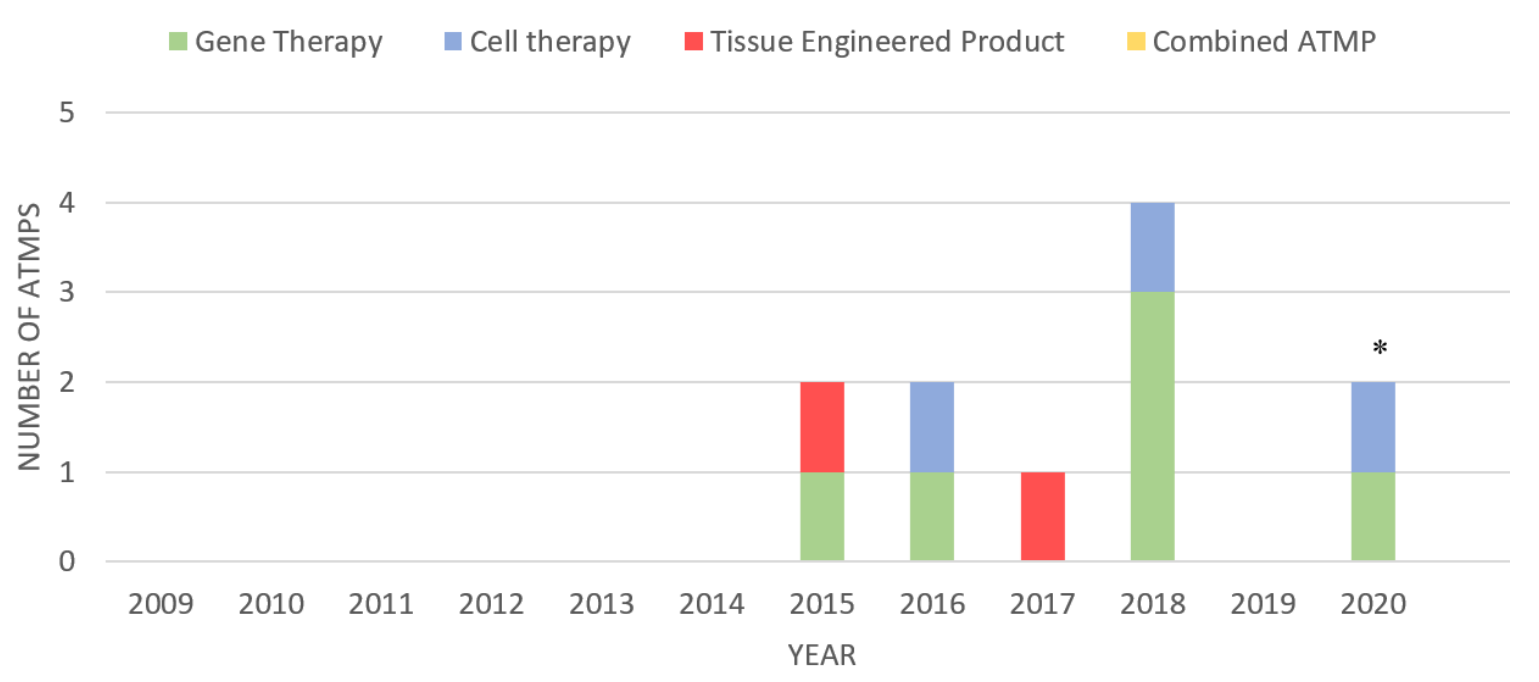

Figure 1. ATMPs (advanced therapy medicinal products; gene therapies, cell therapies, tissue-engineered products and combined ATMPs) that have been granted marketing approval by The EMA. Note: * indicates cell therapy "KTE-X19" expected to receive market authorization in 2020 (the EMA has validated their application but it currently under review [8,9]).

\subsection{Stem Cells}

Stem cells are non-specialized cells found in multicellular organisms and are capable of differentiating into more than 200 types of cell [10]. Their ability to self-renew and their excessive proliferative properties have drawn The attention of researchers and present significant therapeutic potential applications in The lung [11,12]. Stem cells can be used in several applications; stem cells can be isolated and expanded from human tissue and used for The replacement of damaged or injured tissue and The development of personalized medicine. They can also be used for stimulation of injured tissue, investigation of human development, and to broaden The knowledge of complex pathologies of diseases [13]. There are several types of stem cells, embryonic stem cells, adult stem cells (non-embryonic stem cells), hematopoietic stem cells, adipose-derived stem cells, umbilical/derived stem cells, cord blood stem cells, and amniotic fluid stem cells. Stem cells are found in both embryonic and adult cells [14]. Embryonic stem cells are found in The inner mass of blastocytes [15]. There has been a lot of interest in using these cells in repair and tissue regeneration. However, due to The safety and obvious ethical issues that revolve around The use of these cells, most researchers are inclined to use adult stem cells, notably mesenchymal stem cells (MSCs). MSCs also have The added advantages of low immunogenicity, minimized risk of teratoma formation, and high expansion potential ex vivo $[14,16,17]$.

\subsection{Mesenchymal Stem Cells}

MSCs, also known as mesenchymal stromal cells, are multipotent adult stem cells [18]. They are non-hematopoietic, tissue adherent stromal cells, and can be harvested from The bone marrow, cord blood, peripheral blood, fallopian tube, fetal liver, and lung. They are capable of self-renewal without The loss of their characteristics and have The capability of differentiating into different mesodermic and non-mesodermic tissue lineages (see Figure 2) [19]. The international society of cell therapy (ISCT) has set out several requirements regarding The characteristics of MSCs. They must be plastic adherent; they must express CD73, CD90, and CD105 and be absent of CD15, CD34, CD45, CD11, CD-79, CD-19 and HLA-DR. Lastly, under appropriate and specific conditions, they must be able to differentiate into chondrocytes, adipocytes, and osteoblasts [20]. 


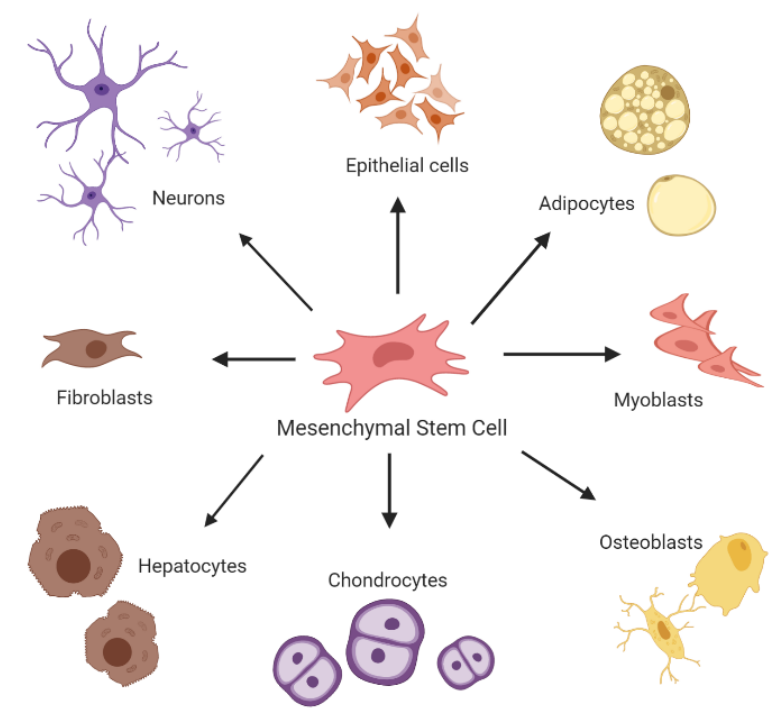

Figure 2. Overview of in-vitro differentiation of MSCs (mesenchymal stromal cells). Note: Figure created with BioRender.com.

MSCs have attracted considerable attention in The last thirty years; they have been studied extensively due to their potential application in medicine and research. MSCs are among The most widely used, well-known and well-documented types of stem cells [21,22]. MSCs' remarkable anti-inflammatory, immunomodulatory, angiogenic, antifibrotic, anti-microbial properties are what has driven The interest in their application in regenerative medicine [23]. Interestingly, MSCs are also known to secrete painkiller molecules [24]. MSCs can reprogram The immune response and reduce the production of pro-inflammatory cytokines. MSC effects are based on their ability to home, engraft, and survive in The injured part of a lung. MSCs subsequently secrete paracrine factors, which in turn repair lung injury. A few paracrine factors that attenuate lung injury are IL-10, hepatocyte growth factor (HGF), and indoleamine 2,3-dioxygenase (IDO) [25]. MSCs' paracrine factors combat factors that promote inflammation, apoptosis, and pathological remodeling (see Figure 3) [26].

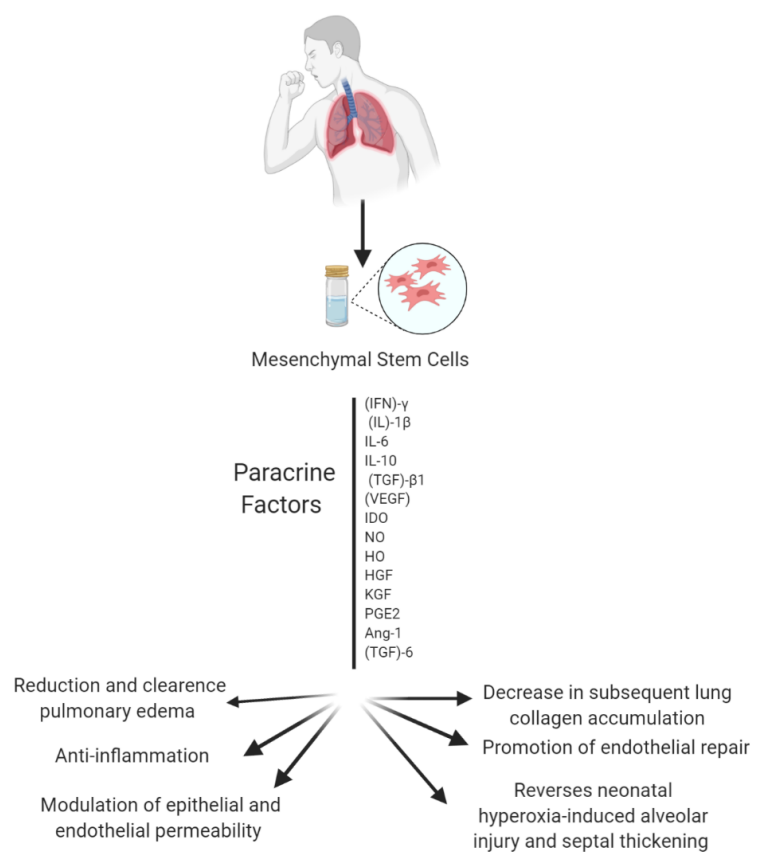

Figure 3. Overview of The several paracrine factors secreted by MSCs that can attenuate lung injury. Note: Figure created with BioRender.com. 


\subsection{Preconditioning and Potentiation of MSCS}

In some instances, MSCs have been demonstrated to not be as effective in harsh environments, such as apoptosis and grave pathophysiological conditions [27]. Prior to administration, in preconditioned MSCs, notably, hypoxic conditioning has not only demonstrated The ability to enhance their functions in vitro and in vivo and protect them from The harmful milieu, but it can also improve homing ability and increase differentiation efficacy $[27,28]$. Collectively, this ameliorates their chances of survival in ischemic conditions. Preconditioning of MSCs entails The exposure of MSCs to unfavorable and stressful conditions such as hyperoxia, hypoxia, hydrogen peroxide, or stimulation of MSCs using various serums and agents such as heat shock proteins (HSP), melatonin or low doses of lipopolysaccharide (LPS) [28,29]. Studies have demonstrated that The use of HSP can protect MSCs against hypoxic-induced apoptosis [30]. Despite The considerable promise of The preconditioning of MSCs, The oxygen level, incubation time, and underlying mechanisms are still yet to be established [28]. Hypoxic conditioning can improve The expression of anti-apoptotic proteins amid ischemic conditions such as gas exchange impairment in ARDS (acute respiratory distress syndrome) [31,32]. To determine The effects of hypoxic preconditioning, Jiang et al. exposed human gingiva derived MSCs to hypoxic conditions of $2 \%$ oxygen. They demonstrated that The hypoxia increased The IL-10 production and The expression of FAS-L, which ultimately enhanced peripheral blood mononuclear cell (PBMC) proliferation and induced PBMC apoptosis [33]. Additionally, in a study carried out by Liu et al., hypoxic MSCs reduced The expression levels of The pro-inflammatory cytokines TNF- $\alpha$, IL-10, and MIP-2, which, in turn, improved The overall lung function in acute ischemia/reperfusion (I/R) lung injury [34]. These two studies demonstrate that The preconditioning of MSCs can enhance their functions in ischemic conditions. Overall, it can enhance their therapeutic benefits in treating lung injury and disease.

\subsection{Conditioned Media (CM)}

Conditioned media is media enriched with a complex mixture of secreted products. Even though its mechanism of action is not yet fully understood, conditioned media has, in some cases, been shown to be better than cell therapies for ischemic and interstitial diseases [35]. Some of The beneficial secreted products by MSCs include cytokines, growth factors, extracellular matrix (ECM) protein, factors in matrix remodeling, and extracellular vesicles [36,37]. Research carried out thus far has shown that conditioned media has The ability to influence cell subtypes from The innate and adaptive immune system. A study carried out by Kim Yong demonstrated that MSC-CM led to The angiogenesis and regeneration of lung damaged by cigarette smoke by inhibiting cell apoptosis, inducing cell proliferation, and restored The expression of ECM proteins [38]. In another study carried out by Hwang et al., MSC-CM media was used to reduce The number of inflammatory cells that could migrate to lung tissue. [37]. A study carried out by Sagaradze et al. demonstrated that MSC-CM reduced the level of pro-inflammatory cytokine production, decreased infiltrating inflammatory cells. Furthermore, there was an increase in T cell subsets and macrophages. Sargaradze commented that even though these results have shown great promise, there is a lack of standards regulating bioprocessing and a lack of The use of auxiliary materials [35]. Additionally, in a study which set out to determine The protective effects of MSC secretome on pulmonary epithelial cells injured by hypoxia, Shologu et al. demonstrated that The pre-treatment of MSC-CM restored The matrix metalloproteinase (MMPs) physiological function in primary alveolar epithelial cells (AECs) that were subjected $0.5-1.5 \% \mathrm{O}_{2}$ hypoxia. This ultimately promoted repair and cellular homeostasis of injured cells [39].

\subsection{MSC Secretome}

Secretome is a term used to define The set of proteins secreted by an organism to The extracellular space $[40,41]$. Secretome is specific and can alter in response to changes in physiological and pathological states and conditions [41]. There are a wide variety of immunomodulatory cytokines and chemokines secreted by MSCs such as growth factors, ECM proteases, hormones, and lipid mediators. 
Collectively these cytokines are known as MSC-secretome [42]. The MSC secretome has The capability of facilitating tissue regeneration, tissue repair, cytoprotection, and angiogenesis [41]. It is also capable of combating processes and factors from diseases such as apoptosis, pro-inflammatory cytokines, and pathological remodeling [42]. Of note, and important in The reliable and reproducible generation of MSC secretome, there is a lack of codified standardized preconditioning methods and The effects that preconditioning could potentially have on The MSC secretome. Nevertheless, and with this variability inherent, one of their main advantages is that they are secreted continuously by MSCs meaning there is less of a need for larger quantities of MSCs for production and treatment which combats The issue of escalating donor shortages $[43,44]$. Furthermore, The MSC secretome offers additional advantages over MSCs, such as complete avoidance of tumorigenicity and emboli formation. The MSC secretome can be administered and researched without The need for extensive expansion methods, a key enabler in their potential as a therapeutic approach $[41,45]$.

\subsection{Extracellular Vesicles (EVs)}

Vesicles can be found in cell culture supernatants, blood, urine, synovial fluid, sputum, pleural effusion, and The alveolar space [44]. The immunosuppressive, protection, and reparative properties of EVs that are isolated from MSC supernatants are similar to MSCs themselves. There are three types of EVs: exosomes, microvesicles, and apoptotic bodies. EVs are categorized on The basis of their origin, size, and mechanism of biogenesis [46,47]. EVs and exosomes are produced from various activities that take place in The cells, while apoptotic bodies are secreted during apoptosis [47]. Natural EVs can deliver therapeutic agents to The desired site. EVs also have several more advantages compared to MSCs. EVs can withstand temperatures as low as $-80{ }^{\circ} \mathrm{C}$ without losing their bioactivity benefits. EVs do not have The ability to self-replicate, so there is a complete avoidance in The formation of tumorigenicity and emboli formation [41,43]. In relation to respiratory diseases, EVs have shown their unique benefits by ameliorating alveolar specification, correcting pulmonary hypertension, and reducing The activating macrophage and pro-inflammatory cytokine levels [48].

\subsection{Exosomes}

Exosomes have been demonstrated to contribute to The therapeutic effects of MSC secretome [49]. Exosomes are nano-sized, non-self-renewing extracellular vesicles that originate in The endopathic pathway. They are then subsequently secreted by MSCs, T-cells, dendritic cells, tumor cells, and mast cells when multivesicular bodies (MVBs) and The plasma membrane fuse together [50,51]. The composition of The exosomal proteome includes cytoplasmic protein, nucleoproteins, and intracellular plasma membrane. Exosomes are involved in several vital roles in biological signaling and cell-cell signaling mediation [50,52]. They are also known to target housekeeping biological processes that operate within various tissues [53]. Exosomes provide several advantages compared to MSCs; they are non-replicating and can be sterilized by filtration due to them being nano-sized [54].

\subsection{Cell Therapies}

Cell therapy can be defined as a therapeutic application of cellular material despite The type of cell or clinical indication that can be administered to an animal or human $[55,56]$. The primary aim of this type of biotherapy is to develop medicinal products and therapeutic strategies to repair and stimulate damaged tissue and organs such as myocardial regeneration, skeletal muscle, and lung tissue [57]. Furthermore, The aim is to ultimately cure diseases and conditions such as lung diseases, neurodegenerative disorders, spinal cord injuries, cancers such as leukemia and melanoma and autoimmune diseases such as diabetes, multiple sclerosis, and rheumatoid arthritis [57-59]. Chemically produced drugs and cell therapy differ in The sense that cellular therapies can be personalized to cure a disease unlike The majority of organic compounds that are developed to suppress symptoms and not to cure a disease [55]. There are two conventional cell therapy approaches: Autologous, patient-specific (the harvesting and expanding of cells from an individual and reintroducing 
them back into The same individual) [60], and allogeneic (patient independent), cells from a donor that are isolated and expanded and reintroduced back into a recipient (see Figure 4) [57,60,61]. In terms of MSCs, studies have demonstrated that autologous cell therapy is a more potent and effective strategy compared to allogenic [62]. In addition, allogenic cell therapy also has its limitations, notably The possibility of immune rejection [63]. However, The choice between The two strategies depends on The circumstance at hand. Preclinical trials have demonstrated that autologous cell therapy may not be The best option for chronic lung disease [64]. It may be challenging to isolate and expand cells from older patients due to their decreased biological activity, or from a patient that is severely ill due to their immune suppression properties and low immunogenicity, and The isolation and expansion of MSCs is a time-consuming process [65]. In terms of lung diseases, and depending on The patient's status, there may not be enough time to isolate and expand The cells of The patient. An off The shelf allogeneic therapeutic strategy would be a viable option for chronic lung diseases.

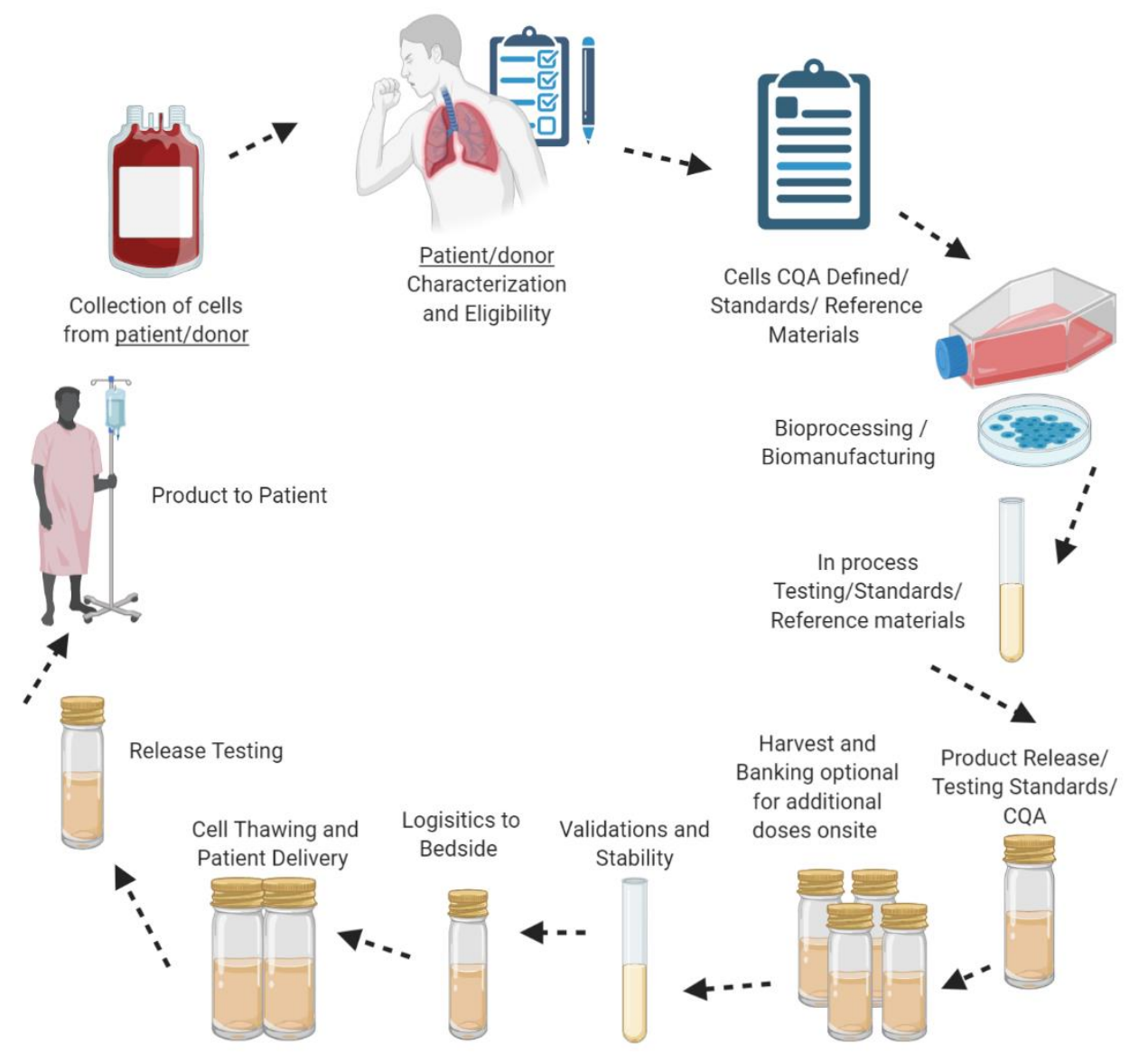

Figure 4. Overview of The production/manufacturing process of autologous and allogeneic cell therapy approaches. Note: Figure created with BioRender.com.

Cell therapies have advanced in The last decade. According to The EMA, there are currently four cell therapies that have been approved for marketing in Europe (See Figure 1). They have garnered significant interest due to their characteristics, long term management, and potential to treat untreatable diseases, however, there are still safety, toxicity and tumorigenicity issues that revolve around the use of pluripotent cellular therapies [66]. To maximize The potential benefits of cell therapies, it is imperative that there are more established strategies and more research on The differentiation and paracrine mechanisms of stem cells and how they integrate and migrate in The body [55]. Nevertheless, with the research and preclinical and clinical studies done thus far, cell therapies and their regenerative abilities will very likely be a valuable asset in The therapeutic arsenal. 


\section{Pulmonary and Respiratory Diseases and Infections}

Lung diseases are common conditions worldwide. They are broadly segmented into those that affect The airways and those that affect The alveoli. The diseases that affect The airways include asthma, chronic obstructive pulmonary disease (COPD), chronic bronchitis, emphysema, acute bronchitis, and cystic fibrosis. The diseases that affect The alveoli include pneumonia, tuberculosis, emphysema, pulmonary edema, lung cancer, acute respiratory distress syndrome, and pneumoconiosis [67]. Cell therapies have been at The forefront of respiratory and pulmonary diseases and infection in the last decade. This review focuses on chronic lung diseases only given that The bulk of The published literature focuses on those, as well as being supported by currently registered clinical trials. Specifically, we shall discuss The potential benefits of cell therapy in The treatment of ARDS, sepsis, and COVID-19.

\subsection{Acute Respiratory Distress Syndrome (ARDS)}

ARDS can be defined as an acute inflammatory life-threatening disease, which results in pulmonary gas exchange failure and ultimately causes The lungs to endure grave injury [68-70]. ARDS can arise from various indirect and direct consequences: direct lung injury, including pneumonia, aspiration of gastric contents and near-drowning and indirect lung injury including sepsis, severe trauma, drug overdose, pancreatitis, and transfusion injury [71]. ARDS can also be The result of intricate interactions with several inflammatory mediators such as TNF- $\alpha$, IL-10, TGF- $\beta$ and IL-6 [72], which result in diffuse alveolar damage, increased intrapulmonary stunts, increased capillary permeability, damage to the capillary endothelium non-cardiogenic pulmonary edema, and surfactant dysfunction [73]. These consequences correlate to The impairment of fluid removal from the alveolar space, which contributes to the accumulation of protein-rich fluid in alveolar, which results in the diffusion of damage in The alveoli [74,75]. Mild, moderate, and severe cases of ARDS are based on The severity of symptoms, The $\mathrm{PaO}_{2} / \mathrm{FiO}_{2}$ ratio, and The level of hypoxemia [70]. The $\mathrm{PaO}_{2} / \mathrm{FiO}_{2}$ ratio is used to indicate The oxygenation status of a patient in The intensive care unit (ICU) and to identify The hypoxemic respiratory failure when supplemental oxygen is being administered to a patient [76]. Mechanical ventilation and other inhalation/respiratory dosage forms are administered to improve tissue oxygenation but may sometimes cause pulmonary injury [74]. ARDS is present in $10 \%$ of patients in The ICU and remains a significant issue. [71,77]. The mortality rate of severe ARDS is approximately $45 \%$ [73]. As of now, no pharmacotherapy exists for The pathophysiological mechanisms of ARDS $[78,79]$. However, ARDS is commonly managed by mechanical ventilation and fluid conservation [71].

\subsection{Sepsis}

Sepsis is a critical and life-threatening medical condition for which no cure currently exists [68,80]. In January 2020, The University of British Columbia stated that sepsis is The leading cause of death globally [81]. Sepsis is also The cause of $50 \%$ of all inpatient deaths and arises when The body has been dramatically affected by bacterial, viral, or fungi infection(s) such as pneumonia, and The consequent inflammation and organ dysfunction [82]. Sepsis is also known as a variant of ARDS. The lung is The most affected organ due to pneumonia being The key starting point of The septic process [83]. Sepsis can affect gas exchange and pulmonary hemodynamic alterations because of increased capillary permeability and pulmonary pressure in The first stages of sepsis [84]. Early symptoms of sepsis include fever, shock, and multi-organ failure as well as hyperinflammatory innate immune responses [85]. Severe sepsis can cause failure to vital organs such as The lungs, kidneys, and liver [68]. Over The years, treatments for sepsis have immensely improved. Treatments and strategies including lung-protective ventilation, prone positioning, extracorporeal membrane oxygenation, fluid resuscitation, antibiotics, anti-microbial therapy, and blood products [82,83]. However, sepsis still has a high mortality rate [86]. 


\subsection{COVID-19}

Coronaviruses are enveloped non-segmented positive-sense RNA viruses that belong to the Coronaviridae family. The majority of human coronaviruses infections are mild [87]. By late December 2019 and early January 2020, it was noted that there were six human cases of novel COVs that had The capability to cause acute respiratory diseases and enteric and central nervous systems infectious and diseases in animals as well as humans: HCoV-229E, HCoV-OC43, HCoV-NL63, HKU1, SARS-CoV and MES-CoV $[88,89]$. Severe acute respiratory syndrome coronavirus (SARS-CoV) and Middle East respiratory syndrome coronavirus (MERS-CoV) are The two novel CoV infections that cause respiratory infections [88]. In December 2019, an outbreak of a novel coronavirus took place in Wuhan, China [90]. By January 2020, WHO (World Health Organization) declared The outbreak a public health emergency of international concern [91]. In February 2020, The novel virus was then isolated, identified, and named SARS-CoV-2 by The World Health Organization [90]. Since The initial detection of The virus, COVID-19 has infected over 25.3 million people and caused an estimated 848,000 deaths globally.

While The vast majority of individuals infected by coronavirus are thought to remain asymptomatic, The physical presentation of COVID-19 is dry cough, fever, chills, headaches, muscle pain, shortness of breath or difficulty breathing, sore throat, or loss of taste or smell [92]. Less common symptoms include sputum and hemoptysis [93]. Reports suggest that The elderly and those who have one or more underlying health conditions appear to have a higher risk of being infected by this disease [94]. As it stands, The medical observation period or quarantine period for people that have tested positive for COVID-19 is 14 days [95]. COVID-19 can cause pneumonia, ARDS, and sepsis, which can lead to long-lasting or permanent damage to The lungs, multiple organ death and, ultimately, death [96]. Medical disciplines have reported that patients that have pneumonia caused by coronavirus had alveoli filled with liquid (pulmonary edema), which can lead to The inability to take in oxygen. ARDS caused by coronavirus is The result of more air spaces becoming filled with fluid leaking from The blood vessels. In addition, COVID-19 patients diagnosed with ARDS lose The ability to breathe on their own $[97,98]$.

Currently, The pathophysiology of COVID-19 is not entirely understood. Researchers have suggested that The coronavirus induces The development and implementation of several pro-inflammatory cytokines (IFN- $\gamma$, IL-1B, IL-6 and IL-12, 1L-2, IL-7, GSCF, IP10, MCP1, MIP1A, and TNF $\alpha$ ) and pro-inflammatory chemokines (CXCL10 and CCL2). The cytokine and chemokines released subsequently initiate viral replication and infiltration $[99,100]$. However, it is The dysregulated activity of these cytokines and chemokines that results in The grave manifestations of COVID-19. In this paper, The term used to describe this phenomenon is "the cytokine storm". The virus first travels down the respiratory tract and induces an innate immune response [101]. Inflammatory exudates and erythrocytes migrate into The alveoli which results in dyspnea and respiratory damage [102]. The cytokine storm results in alveolar damage with fibrin-rich hyaline membranes and a few multinucleated giant cells, epithelial cell proliferation, and increase of macrophages [101]. The debris from this damage then builds up and begins to cover The alveoli. The alveoli then become thicker than usual, impeding gaseous exchange [99,103]. The blood vessels around The alveoli weaken, which allows fluid to seep into The lung cavities, resulting in respiratory failure (see Figure 5).

The immune capacity of some antivirals is not strong enough to combat The cytokine cascade [104]. Antivirals, antibiotics, and biologics such as hydroxychloroquine, favipiravir, and tocilizumab have a significant effect on The underlying processes of COVID-19. However, The approach of this kind carries with it well-known limitations such as combating The cytokine storm. These pharmacological therapies can induce a range of adverse effects and outcomes which can cause morbidity and mortality [105]. Systemic corticosteroids can be effective but may reduce essential immune activity [106]. In addition, viruses, notably COVID-19, have The ability to suppress $\mathrm{T}$ cell functions which can make some of these therapies inefficacious [105]. 


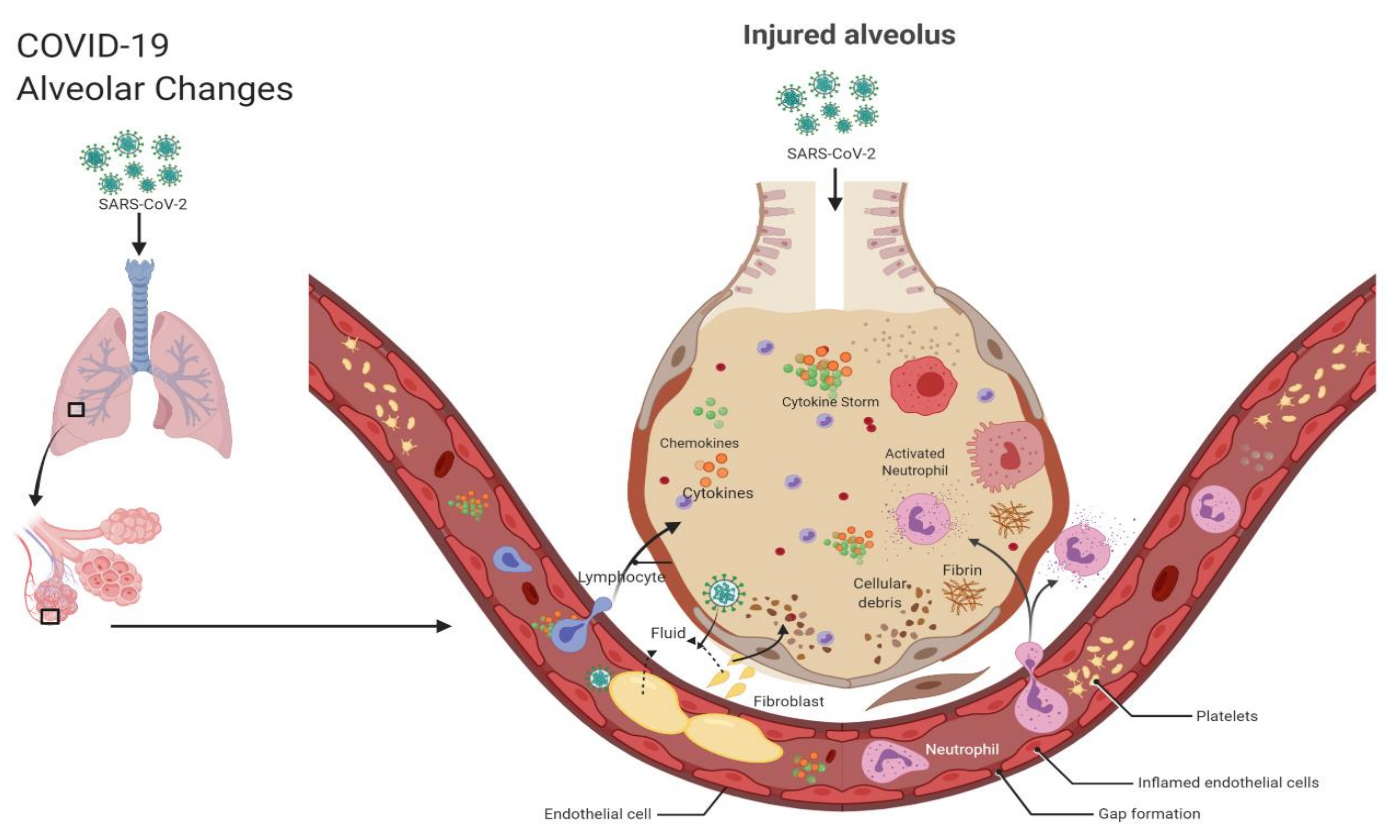

Figure 5. COVID-19 alveolar changes. Note: Figure created with BioRender.com.

\section{Route of Administration}

There are a variety of administration routes that can be used to administer a drug. The route of administration can either be enteral, parenteral, or topical [107]. The parenteral routes are intravenous (a drug given into a peripheral vein 1-2 min by infusion), intramuscular, subcutaneous, intra-arterial, and intradermal. Enteral dosage forms include oral, sublingual, buccal, or rectal. Intravenous (IV), intramuscular (IM), and subcutaneous (SC) are The most common parenteral routes [108]. The localization and persistence of MSCs after IV administration to The lung remains unknown. The route of administration is crucial due to The fact that it ultimately determines The fate of a drug, in this instance ATMPs. In some cases, standard drug delivery systems can be unsuccessful or ineffective because of their inability to deliver therapeutic agents to a target [109].

\subsection{Intravenous Administration}

The intravenous route is often The preferred route due to its ability to deliver large doses of medication to The body directly. Whilst not effective in delivering large doses of The therapeutic to The lung, some formulation strategies such as excipient choice, or even addition of lung-targeting ligands may increase drug concentration to a therapeutic level in The lung and can reduce its distribution and losses within other organs and tissues [109]. An advantage of using The intravenous route is its ease of application. However, there may be difficulty finding suitable veins, and associated tissue damage. The administration of MSCs via intravenous routes have been studied thoroughly. Of relevance here, MSCs that avoid first pass losses naturally migrate to The lung after administration and are usually trapped in The lung. MSCs then repair sites of injury via their immunomodulatory effects $[110,111]$.

\subsection{Intratracheal Instillation}

Intratracheal instillation is The process by which liquid is introduced into a lung instantaneously via an intratracheal tube or microsprayer device. Instillation is not a physiological route for humans [112]. There are several advantages in that only a small amount of therapeutic is needed, and The doses can be precisely administered to The respiratory tract [113]. That said, intratracheal instillation may lead to inconsistent deposition, largely in The upper airways (heterogenous distribution), and medication tends to rely on a gravitational and regular mucociliary beat to disperse throughout The lung, thus leading to inconsistent deposition patterns [113]. Xisto's comparative study in 2011 hypothesized 
that intratracheal administration was more effective than intravenous administration when modulating The inflammatory and fibrogenic "process" [114].

\subsection{Inhalation}

Inhalation therapy has been used for 1000 years [115]. In The last ten years, there have been significant advancements to inhalation drug therapies and new drug products for respiratory disease and fascinating neurological diseases [116]. Inhalation/aerosol drug delivery has played a significant role in many lung and respiratory diseases.

\subsection{Aerosolization}

Aerosols commonly consist of fine solids or liquid particles that are suspended in air or gas [117]. Aerosol therapy is generally used in critical pulmonary treatment [118]. There are several advantages that make aerosol drug delivery a preferred route of administration over various other types of dosage forms: It can be self-administered by patients, parents, and caregivers [119-122]. Various quantities of medication can be quickly released from a container without The risk of contamination or exposure to The remaining medicines [121,122]. The four most commonly used aerosol drug devices are nebulizers (NEB), soft mist inhalers (SMI), pressurized metered-dose inhalers (pMDI), and dry-powder inhalers (DPI) [123]. The development of pharmaceutical aerosol technology began with The MDI (metered-dose inhaler) [123]. The first MDI was reported in 1956 by Riker Laboratories Inc. [119,123].

\subsection{Nebulizers}

Nebulizers convert liquid substances into an aerosol. There are three types of nebulizers: jet nebulizers, mesh nebulizers and ultrasonic nebulizers. Nebulizers have The ability to deliver larger doses of medicines without The need for patient coordination [115]. MDIs are The most frequently used type of nebulizer and are used for various lung diseases such as severe asthma and chronic obstructive pulmonary disease. Even though nebulization therapy has many benefits, many nebulizers, such as jet nebulizers, have several limitations, poor drug solubility, and are unable to consistently deliver accurate and consistent medication [121]. The closed circuit, vibrating mesh type nebulizers do not have The same technological limitations, and may represent The most appropriate choice for ATMPs. Additionally, The majority of The current literature on aerosolized ATMPs makes use of vibrating mesh nebulizers. One of The main advantages of nebulizers is that they are capable of nebulizing a variety of therapeutics. Other benefits include The ability to modify The dosage amount administered to a patient [120].

\section{Pre-Clinical Studies}

\subsection{ARDS}

Recent studies have shown that cell therapies, specifically MSCs, MSC-CM, exosomes, and conditioned media, hold great promise in The treatment of ARDS [124]. MSC therapy is an exciting prospect because it can respond to The level and nature of an injury $[74,75]$.

It has been debated that the lung has limited regenerative capacities [64,74]. However, as we have set out above, therapies such as MSC secretome, exosomes and conditioned media can be produced and stored and still maintain their viability prior to administration. Moreover, studies have demonstrated that cellular therapies consequently enhance cellular functions to regenerate circulating stem cells and attenuate survival when cells are administered directly to the bronchial tree in animal models [74,125]. In A study carried out by Maron-Gutierrez et al. A set of BALB/c mice were randomly administered saline or bone marrow-mesenchymal stem cells (BM-MSCs) intravenously. After day 1, there was a significant reduction in lung inflammation and increased remodeling, resulting in the improvement of lung mechanics in the extrapulmonary models [32]. In A separate study carried out by Cardenes et al., BM-MAPCs were administered to sheep to investigate the biodistribution of MAPCs for the treatment 
of ARDS. After 1 to $5 \mathrm{~h}$, the cells had biodistributed to A variety of organs with the lung being the primary organ of retention. MAPCs also influenced arterial oxygenation recovery [126]. A study conducted by Gupta demonstrated that when MSCs were administered via an intrapulmonary route not only was there an improved survival rate of mice but they also reported downregulation of pro-inflammatory immune responses to endotoxin and also an increase in anti-inflammatory cytokines IL-10 [125]. Ionescu et al. demonstrated that MSC-CM led to the attenuation of lung inflammation and promotion of wound healing/anti-inflammatory M2 macrophage phenotype in part via IGF-1. This collectively results in alleviation of LPS-induced lung injury [127]. Similar to Ionescu et al., MSC-CM also attenuated LPS-induced ALI by the promotion of neutrophil apoptosis. Su et al. suggest that the treatment for LPS-induced ALI consists of the regulation of apoptosis in neutrophils, A crucial factor in alleviating LPS-induced inflammation [128]. Together, these studies suggest that MSC-CM could be A considerable alternative for treating ARDS.

\subsection{Sepsis}

There are no treatments that directly target the pathogenesis of dysregulated inflammation and tissue injury [129]. the pleiotropic effects of stem cells have the potential to intervene at various levels in the pathophysiology of sepsis in murine models, and subsequently reduce excessive inflammation which can prevent organ damage and could potentially reduce the rate of mortality [130]. Mesenchymal stem cell-based therapy has been shown to reduce severe bacterial sepsis in murine models because of their immunomodulatory and anti-microbial properties [131]. a study carried out by Gonzalez-Rey et al. showed that human or murine adipose-derived mesenchymal stem cells (AD-MSCs) in a sepsis model increased survival in mice [132]. In addition, stem cells have also demonstrated the ability to secrete growth factors in response to LPS and tumor necrosis factor that can result in the reduction of apoptosis and organ injury [133].

Of note, these results sometimes do not carry over in larger animal models. In a study carried out by Horak et al., one dose of BM-MSCs was administered to pigs. That group demonstrated that The infusion of MSCs was well tolerated, but The MSCs failed to ameliorate The septic conditions and failed to modulate The immune system's inflammatory response [134]. This study is heavily contrasted with a study conducted by Laroye et al., where umbilical cord-mesenchymal stem cells (UC-MSCs) improved The survival of pigs by attenuating The hypotension, hyperlactatemia, and multiple organ failure [135]. Horak et al. suggests The immunomodulatory capacities of BM-MSCs and UC-MSCs may differ [134]. Furthermore, this discrepancy could be attributed to The limited ability of bone marrow-derived MSCs to secrete paracrine factors needed to attenuate septic pathophysiological conditions [136]. These findings, while preliminary, suggest that extensive research on a cell type and cell therapy type should be conducted prior to it being applied to a study. Furthermore, importantly, one should perhaps implement a preconditioning or potentiation process prior to BM-MSC administration to enhance their pleiotropic effects.

\subsection{Aerosolization of Stem Cells In Vivo And In Vitro}

The debate continues about The best strategies to administer MSCs, EVs, and MSC-CM for The treatment of respiratory and pulmonary diseases. There is also growing interest in The use of safe and more effective administration routes for respiratory disease treatment [137]. A limited amount of literature has been published on The effect of aerosolized stem cells and their benefits in treating respiratory diseases. Studies have demonstrated that nebulizers facilitate a high efficiency compared to various parenteral routes. Moreover, accumulated evidence and findings from preclinical studies investigating aerosolized MSCs supports The theory that inhalation and aerosolization of stem cells not only can lead to a high level of distribution of stem cells in The lung, but also stem cells maintain a high level of viability [83], and there is also a minimized risk of cell loss and morphological changes [138].

Aerosolized MSCs expressing angiopoietin-1 were investigated to demonstrate their effects in asthma-related airways in a rabbit. Their findings demonstrated that MSCs attenuated The airway 
inflammation and structural changes and also reduced The expression of various pro-inflammatory genes [138]. The use of aerosolized MSCs alone significantly reduced The levels of IL-4 and TGF- $\beta$. This study also compared aerosolized MSCs to non-aerosolized MSCs. The cell morphology of The aerosolized MSCs and The non-aerosolized MSCs demonstrated a significant difference between them. Furthermore, The aerosolized MSCs showed a high level of viability even though there was pressure on The MSCs during The aerosolization process [138]. Similarly, a study carried out in 2016 by Kim et al. demonstrated that atomized MSCs maintained a high level of viability [83]. In a comparative study by Averyanou et al., rabbits were administered MSCs via intravenous and inhalation routes. Five rabbits were administered $2 \times 10^{6}$ MSCs via intravenous infusion. Their primary aim was to evaluate The survival rate of MSCs. This was demonstrated by using three types of nebulizers: jet, ultrasound, and mesh nebulizers. After 28 days, they assessed The morphological changes in bronchoalveolar lavage fluid (BALF). The jet nebulizer demonstrated The highest level of survival. It was also noted that there was evidence of significant antifibrotic effects on bleomycin-induced lung fibrosis [139].

The pioneering work carried out by Alhasan et al. investigated The viability of aerosolized MSCs under surface acoustic wave (SAW) nebulization. They demonstrated that SAW nebulization had no adverse effects on The cell metabolic rate, proliferation, or phenotypic characteristics compared to The non-nebulized MSCs [140]. A growing body of studies has investigated The concept of nebulized MSCs, MSC-CM, and MSC-secretome. MCS-CMs compatibility with vibrating mesh was first demonstrated by McCarthy et al., where MSC-CM inhibited The proliferation of pathogens via nebulization. This was demonstrated by nebulizing MSC-CM, collecting The aerosol and determining The antibacterial properties [141]. This result can be compared to a later study carried out Averyanov in 2018; that group demonstrated The compatibility of MSCs with three different types of nebulizers. In his study, The MSCs passed through The compressor nebulizer maintained a high level of viability followed by The ultrasonic of which only $20 \%$ of cells were viable and, surprisingly, there were no viable cells after they passed through a mesh nebulizer [142]. These findings indicate that MSCs may not be compatible with certain types of nebulizers; however, MSC-CM, MSC secretome, and exosomes may be compatible. Therefore, cell-based therapy compatibility with nebulizers will need extensive research prior this strategy being used in a clinical setting.

The evidence and findings presented in preclinical trials thus far have made MSC therapy attractive to clinical settings. A considerable amount of literature has been published on The potential benefits of MSCs. Every year millions of euros are invested in The planning and conducting of innovative clinical trials. These studies have shown that MSCs have a profound number of unique benefits and can be a promising treatment for pulmonary and respiratory diseases. To date, there are over 75 MSC-related clinical trials registered for ARDS, sepsis, and COVID-19 that are showing positive results (see Tables 1-3). A significant number of these clinical trials primarily focus on The safety and efficacy of administering MSCs (see Figure 6). However, several clinical trials lack results and publications on their findings. Furthermore, many of these trials mimic trials that have proven to be successful from findings published. It is clear that studies are beginning to evolve, and positive trends will emerge. The majority of clinical trials have demonstrated that The most common route of administration of MSCs is intravenous. 
Table 1. Mesenchymal stem cell (MSC)-based therapy clinical trials for ARDS (acute respiratory distress syndrome).

\begin{tabular}{|c|c|c|c|c|c|c|c|c|}
\hline NCT No. & Title & Status & Company Name & Disease/Conditions & Route of Administration & Intervention/Mechanism Target & Results & Phase \\
\hline NCT01775774 & $\begin{array}{l}\text { Human MSCs for acute respiratory } \\
\text { distress syndrome }\end{array}$ & Completed & University of California & ARDS & Intravenous & $\begin{array}{c}\text { Participants received } 1 \times 10^{6}, \\
5 \times 10^{6} \text { and } 10 \times 10^{6} \text { cells } / \mathrm{kg} \text { body } \\
\text { weight of allogenic BM-HMSCs }\end{array}$ & $\begin{array}{l}\text { A single dose } \\
\text { of MSCs } \\
\text { demonstrated to } \\
\text { be safe and was } \\
\text { tolerated well }\end{array}$ & 1 \\
\hline NCT02611609 & $\begin{array}{l}\text { A phase } 1 \text { and } 2 \text { study to assess } \\
\text { multistem therapy in acute respiratory } \\
\text { distress syndrome }\end{array}$ & Completed & Athersys, Inc & ARDS & Intravenous & MultiStem ${ }^{\circledR}$ & N/A & 1 and 2 \\
\hline NCT03608592 & $\begin{array}{l}\text { Human Umbilical Cord Mesenchymal } \\
\text { stem cells (MSC) therapy in ARDS }\end{array}$ & Recruiting & $\begin{array}{l}\text { Lv Haijin, Sun Yat-sen } \\
\text { University }\end{array}$ & ARDS & Intravenous & $\begin{array}{c}60 \times 10^{6} \text { UC-MCSs intravenously } \\
\text { administered in } 2 \mathrm{~h}\end{array}$ & N/A & N/A \\
\hline NCT01902082 & $\begin{array}{l}\text { Adipose-derived Mesenchymal stem } \\
\text { cells in acute respiratory distress } \\
\text { syndrome }\end{array}$ & Unknown & Shaoxing Second Hospital & ARDS & Intravenous & $\begin{array}{l}\text { Participants will receive } 1 \times 10^{6} \\
\text { Adipose-derived MSCs on day } 2 \text {. }\end{array}$ & $\mathrm{N} / \mathrm{A}$ & 1 \\
\hline NCT02804945 & $\begin{array}{c}\text { Mesenchymal Stem cells (MSCs) for } \\
\text { The treatment of Acute Respiratory } \\
\text { Distress Syndrome (ARDS) in patients } \\
\text { with Malignancies }\end{array}$ & Completed & Anderson Cancer Center & ARDS & $\begin{array}{l}\text { Intravenous infusion } \\
\text { "MSCs by vein" }\end{array}$ & $\begin{array}{c}\text { Participants received } 3 \times 10^{6} \\
\text { intravenously administered on } \\
\text { day } 1\end{array}$ & $\mathrm{~N} / \mathrm{A}$ & 1 \\
\hline NCT03042143 & $\begin{array}{l}\text { Repair of Acute Respiratory Distress } \\
\text { Syndrome by Stromal cell } \\
\text { Administration (COVID-19) (Realist) }\end{array}$ & Recruiting & $\begin{array}{l}\text { Belfast Health and Social } \\
\text { Care Trust }\end{array}$ & COVID/ARDS & Intravenous & $\begin{array}{l}\text { Participants will receive max. } \\
\text { tolerated dose of human umbilical } \\
\text { cord derived CD362 enriched } \\
\text { MSCs given in 30-90 min. }\end{array}$ & N/A & 1 and 2 \\
\hline NCT04347967 & $\begin{array}{l}\text { Mesenchymal stem cells for } \\
\text { The treatment of Acute Respiratory } \\
\text { Distress Syndrome (ARDS) }\end{array}$ & Not recruiting yet & Meridigen Biotech Co. Ltd. & ARDS & Intravenous Infusion & $\begin{array}{l}\text { Participants will receive low, } \\
\text { medium, and high doses of } \\
\text { UMC119-06 given to } 3 \text { different set } \\
\text { of people }\end{array}$ & N/A & 1 \\
\hline NCT03818854 & $\begin{array}{l}\text { Mesenchymal Stromal Cells for Acute } \\
\text { Respiratory Distress Syndrome (STAT) }\end{array}$ & Recruiting & University of California & ARDS & Intravenous & $\begin{array}{l}\text { Participants will receive } 10 \times 10^{6} \\
\text { cells given over } 60-80 \mathrm{~min}\end{array}$ & N/A & 2 \\
\hline NCT04377334 & $\begin{array}{c}\text { Mesenchymal Stem cells (MSCs) in } \\
\text { inflammation-Resolution Programs of } \\
\text { Coronavirus Disease 2019 (COVID-19) } \\
\text { Induced Acute Respiratory Distress } \\
\text { Syndrome (ARDS) }\end{array}$ & Not Recruiting Yet & $\begin{array}{l}\text { University Hospital } \\
\text { Tuebingen }\end{array}$ & ARDS/COVID & Intravenous & $\begin{array}{l}\text { Participants will receive allogenic } \\
\text { bone marrow derived HMSCs }\end{array}$ & N/A & 2 \\
\hline NCT02444455 & $\begin{array}{l}\text { Human Umbilical-Cord-Derived } \\
\text { Mesenchymal Stem Cell Therapy in } \\
\text { Acute Lung Injury (UCMSC-ALI) }\end{array}$ & Unknown & $\begin{array}{l}\text { Affiliated Hospital to } \\
\text { Acadmey of Military } \\
\text { Medical Sciences }\end{array}$ & ARDS/ALI & Intravenous & $\begin{array}{l}\text { Participants will/would receive } \\
5 \times 10^{5} \text { cells } \mathrm{kg} / \mathrm{body} \text { weight of } \\
\text { human UC-MCSs on day 2, } \\
\text { and } 14\end{array}$ & $\mathrm{~N} / \mathrm{A}$ & 1 and 2 \\
\hline NCT02215811 & $\begin{array}{c}\text { Treatment of Severe Acute Respiratory } \\
\text { Distress syndrome with allogenic bone } \\
\text { marrow-derived Mesenchymal } \\
\text { Stromal cells }\end{array}$ & Unknown & Karolinska University & ARDS & N/A & $\begin{array}{l}\text { Participants will/would receive } \\
\text { biological MSCs }\end{array}$ & N/A & 1 \\
\hline NCT02112500 & $\begin{array}{l}\text { Mesenchymal stem cell in patients } \\
\text { with acute severe respiratory } \\
\text { failure (STELLAR) }\end{array}$ & Unknown & Asan Medical Center & $\begin{array}{l}\text { Respiratory } \\
\text { Distress } \\
\text { Syndrome }\end{array}$ & Intravenous & $\begin{array}{l}\text { Participants will/would receive } \\
\text { biological MSCs }\end{array}$ & N/A & 2 \\
\hline
\end{tabular}


Table 1. Cont.

\begin{tabular}{|c|c|c|c|c|c|c|c|c|}
\hline 2020-001505-22 & $\begin{array}{l}\text { Phase } 1 / 2 \text { clinical study to assess } \\
\text { The feasibility, safety, tolerability, and } \\
\text { preliminary efficacy of } \\
\text { The administration of HCR040, a drug } \\
\text { whose active substance is HC016, } \\
\text { allogeneic adipose-derived adult } \\
\text { mesenchymal stem cells expanded and } \\
\text { pulsed with } \mathrm{H}_{2} \mathrm{O}_{2}, \text { in patients with } \\
\text { acute respiratory distress syndrome. } \\
\text { (included patients COVID-19) } \\
\text { Double-blind, randomized, parallel, } \\
\text { placebo-controlled pilot clinical trial, } \\
\text { nested in a prospective cohort } \\
\text { observational study, for The evaluation } \\
\text { of The efficacy and safety of two doses } \\
\text { of WJ-MSC in patients with acute } \\
\text { respiratory distress syndrome } \\
\text { secondary to infection by COVID-19 }\end{array}$ & Ongoing & Banc de Sang I Teixits & ARDS & Intravenous & $\begin{array}{l}\text { Participants will receive HCR040 } \\
\text { (allogenic adipose derived adult } \\
\text { mesenchymal stem cells pulsed } \\
\text { with } \mathrm{H}_{2} \mathrm{O}_{2} \text { ) }\end{array}$ & $\begin{array}{l}\text { No results } \\
\text { available }\end{array}$ & 1 and 2 \\
\hline NCT04447833 & $\begin{array}{l}\text { Mesenchymal Stromal Cell Therapy } \\
\text { for The Treatment of Acute Respiratory } \\
\text { Distress Syndrome (ARDS-MSC-205) }\end{array}$ & Recruiting & Uppsala University & ARDS & Intravenous & $\begin{array}{c}1 \text { st } 3 \text { participants will receive } 1 \times \\
10^{6} \text { and next } 6 \text { participants will } \\
\text { receive } 2 \times 10^{6} \text { of allogenic } \\
\text { BM-MSCs }\end{array}$ & N/A & 1 \\
\hline NCT04456361 & $\begin{array}{l}\text { Use of Mesenchymal Stem Cells in } \\
\text { Acute Respiratory Distress Syndrome } \\
\text { Caused by COVID-19 }\end{array}$ & $\begin{array}{l}\text { Active, not } \\
\text { recruiting }\end{array}$ & $\begin{array}{l}\text { Instituto de Medicina } \\
\text { Regenerativa }\end{array}$ & $\begin{array}{l}\text { ARDS, Human } \\
\text { COVID-19 }\end{array}$ & Intravenous & $\begin{array}{l}\text { Participants will receive } 1 \times 10^{8} \\
\text { dose of Wharton jelly MSCs }\end{array}$ & N/A & 1 \\
\hline NCT03807804 & $\begin{array}{l}\text { Efficacy and Safety Study of HLCM051 } \\
\text { (MultiStem }{ }^{\circledR} \text { for Pneumonic Acute } \\
\text { Respiratory Distress Syndrome } \\
\text { (ONE-BRIDGE) }\end{array}$ & Recruiting & Healios K.K. & $\begin{array}{l}\text { Respiratory } \\
\text { Distress } \\
\text { Syndrome }\end{array}$ & Intravenous & $\begin{array}{c}\text { One dose of HCLMOS1 consisting } \\
\text { of } 9.0 \times 10^{8} \text { of cells }\end{array}$ & N/A & 2 \\
\hline NCT04371393 & MSCs in COVID-19 ARDS & Recruiting & $\begin{array}{c}\text { Icahn School of Medicine at } \\
\text { Mount Sinai }\end{array}$ & ARDS, COVID-19 & Intravenous & $\begin{array}{c}\text { One dose of } 2 \times 10^{6} \mathrm{MSCs} \text { cells/ } / \mathrm{kg} \\
\text { body weight }\end{array}$ & N/A & 3 \\
\hline NCT02095444 & $\begin{array}{l}\text { Using Human Menstrual Blood Cells } \\
\text { to Treat Acute Lung Injury Caused by } \\
\text { H7N9 Bird Flu Virus Infection }\end{array}$ & Unknown & $\begin{array}{l}\text { S-Evans Biosciences } \\
\text { Co., Ltd. }\end{array}$ & $\begin{array}{l}\text { ALI/ARDS and } \\
\text { multiple organ failure }\end{array}$ & Intravenous & $\begin{array}{l}\text { Participants will receive } 1 \text { dose of } \\
1 \times 10^{7} \text { menstrual blood stem } \\
\text { cells/kg body weight twice a week } \\
\text { for } 2 \text { weeks }\end{array}$ & N/A & 1 and 2 \\
\hline NCT04345601 & $\begin{array}{l}\text { Mesenchymal Stromal Cells for } \\
\text { The Treatment of SARS-CoV-2 Induced } \\
\text { Acute Respiratory Failure } \\
\text { (COVID-19 Disease) }\end{array}$ & Not recruiting yet & Baylor College of Medicine & ARDS/ COVID-19 & Intravenous & $\begin{array}{l}\text { Participants will receive } \\
1 \times 10^{8} \mathrm{MSCs} \text {. }\end{array}$ & N/A & $\begin{array}{l}\text { Early } \\
\text { phase } \\
1\end{array}$ \\
\hline NCT04452097 & $\begin{array}{l}\text { Use of hUC-MSC Product (BX-U001) } \\
\text { for The Treatment of COVID-19 } \\
\text { With ARDS }\end{array}$ & Not recruiting yet & Baylx Inc. & ARDS/COVID-19 & Intravenous & $\begin{array}{l}\text { Participants will receive } 1 \text { dose of } \\
0.5 \times 10^{6}, 1.0 \times 10^{6} \text { or } 1.5 \times 10^{6} \\
\text { cells } / \mathrm{kg} \text { of body weight }\end{array}$ & N/A & 1 \\
\hline
\end{tabular}


Table 1. Cont.

\begin{tabular}{|c|c|c|c|c|c|c|c|c|}
\hline NCT04400032 & $\begin{array}{l}\text { Cellular Immuno-therapy for } \\
\text { COVID-19 Acute Respiratory Distress } \\
\text { Syndrome-Vanguard (CIRCA-19) }\end{array}$ & Not recruiting yet & $\begin{array}{l}\text { Ottawa Hospital } \\
\text { Research institute }\end{array}$ & COVID-19, ARDS & Intravenous & $\begin{array}{l}75 \times 10^{6}, 150 \times 10^{6} \text { and } 270 \times 10^{6} \\
\text { BM-MSCs given to } 2 \text { sets of groups }\end{array}$ & N/A & 1 \\
\hline NCT04331613 & $\begin{array}{l}\text { Safety and Efficacy of CAStem for } \\
\text { Severe COVID-19 Associated } \\
\text { With/Without ARDS }\end{array}$ & Recruiting & $\begin{array}{l}\text { Chinese Academy } \\
\text { of Sciences }\end{array}$ & $\begin{array}{l}\text { COVID-19, Acute } \\
\text { Respiratory } \\
\text { Distress Syndrome, } \\
\text { Pneumonia and } \\
\text { Acute Lung Injury }\end{array}$ & Intravenous & $\begin{array}{c}3 \text { cohorts with } 3 \text { patients will } \\
\text { receive } 3 \times 10^{6}, 5 \times 10^{6} \text { and } \\
10 \times 10^{6}\end{array}$ & N/A & 1 and 2 \\
\hline NCT04390152 & $\begin{array}{c}\text { Safety and Efficacy of Intravenous } \\
\text { Wharton's jelly derived Mesenchymal } \\
\text { stem cells in acute respiratory distress } \\
\text { syndrome due to COVID-19 }\end{array}$ & Not recruiting yet & BioXcelleraltor & COVID-19, ARDS & Intravenous & $\begin{array}{l}\text { Participants will receive } 2 \text { doses of } \\
50 \times 10^{6} \text { WJ MSC and } \\
\text { hydroxychloroquine, lopinavir or } \\
\text { azithromycin and } \\
\text { ventilation support }\end{array}$ & $\mathrm{N} / \mathrm{A}$ & 1 and 2 \\
\hline NCT04345601 & $\begin{array}{l}\text { Mesenchymal Stromal cells for } \\
\text { The treatment of SARS-CoV-2 Induced } \\
\text { Acute Respiratory Failure (COVID-19 } \\
\text { Disease) }\end{array}$ & Not recruiting yet & Baylor College of Medicine & COVID-19, ARDS & Intravenous & $\begin{array}{l}\text { Participants will be given } \\
1 \times 10^{8} \text { MSCs }\end{array}$ & N/A & 1 \\
\hline NCT04390139 & $\begin{array}{l}\text { Efficacy and safety of Evaluation of } \\
\text { Mesenchymal stem cells for } \\
\text { The treatment of patients with } \\
\text { Respiratory Distress Due to COVID-19 } \\
\text { (COVIDMES }\end{array}$ & Recruiting & Banc de Sang i Teixits & COVID-19, ARDS & Intravenous & $\begin{array}{l}\text { Participants will receive } 1 \times 10^{6} \\
\text { cells/kg body weight W-J MSCs on } \\
\text { day } 1 \text { and day } 3\end{array}$ & $\mathrm{~N} / \mathrm{A}$ & 1 and 2 \\
\hline NCT04399889 & $\begin{array}{l}\text { Human Cord Tissue- MSCs for } \\
\text { COVID-19 }\end{array}$ & Not recruiting yet & Joanne Kurtzberg, MD & COVID-19, ARDS & Intravenous & $\begin{array}{c}\text { Participants will receive } \\
\text { hCT-MSCs }\end{array}$ & $\mathrm{N} / \mathrm{A}$ & 1 and 2 \\
\hline NCT04355728 & $\begin{array}{l}\text { Use of UC-MSCs for } \\
\text { COVID-19 Patients }\end{array}$ & Recruiting & $\begin{array}{l}\text { Camillo Ricordi, University } \\
\text { of Miami }\end{array}$ & $\begin{array}{l}\text { COVID-19. ARDS, } \\
\text { Acute Lung Injury }\end{array}$ & Intravenous & $\begin{array}{l}\text { Participants will receive } 1 \times 10^{8} \\
\text { UC-MSCs and standard treatment }\end{array}$ & N/A & 1 and 2 \\
\hline NCT04377334 & $\begin{array}{c}\text { Mesenchymal Stem Cells (MSCs) in } \\
\text { inflammation-resolution programs of } \\
\text { Coronavirus Disease } 2019 \text { (COVID-19) } \\
\text { Induced Acute Respiratory Distress } \\
\text { Syndrome (ARDS) }\end{array}$ & Not recruiting yet & $\begin{array}{l}\text { University Hospital } \\
\text { Tuebingen }\end{array}$ & COVID-19, ARDS & Intravenous & $\begin{array}{l}\text { Participants will receive allogenic } \\
\text { bone marrow-derived human } \\
\text { mesenchymal stem cells }\end{array}$ & $\mathrm{N} / \mathrm{A}$ & 2 \\
\hline NCT04348461 & $\begin{array}{l}\text { Battle Against COVID-19 Using } \\
\text { Mesenchymal Stromal Cells }\end{array}$ & Not recruiting yet & $\begin{array}{l}\text { Instituto de Investigacóin } \\
\text { Sanitaria de la Fundación } \\
\text { Jieménez Díaz }\end{array}$ & $\begin{array}{l}\text { COVID-19, } \\
\text { Respiratory } \\
\text { Distress } \\
\text { Syndrome }\end{array}$ & Intravenous & $\begin{array}{c}\text { Participants to receive } 2 \text { doses of } \\
1.5 \times 10^{6} \text { ad-MSCs cells } / \mathrm{kg} \\
\text { body weight }\end{array}$ & N/A & 2 \\
\hline NCT04367077 & $\begin{array}{l}\text { MultiStem Administration for } \\
\text { COVID-19 Induced ARDS } \\
\text { (MACoVIA) (MACoVIA) }\end{array}$ & Recruiting & Athersys & COVID-19, ARDS & Intravenous & $\begin{array}{l}\text { Participants to receive doses } \\
\text { of MultiStem }\end{array}$ & N/A & 2 and 3 \\
\hline
\end{tabular}

N/A = Not yet available. 
Table 2. MSC-based therapy clinical trials for sepsis.

\begin{tabular}{|c|c|c|c|c|c|c|c|c|}
\hline NCT No. & Title & Status & Company Name & Disease/Conditions & Route of Administration & Intervention/Mechanism Target & Results & Phase \\
\hline NCT02789995 & $\begin{array}{l}\text { Dysfunctions of human muscle stem } \\
\text { cells in Sepsis }\end{array}$ & Completed & Institut Pasteur & Sepsis & Intravenous Donation & $\begin{array}{l}\text { Study of patients with or without } \\
\text { sepsis, blood and bone marrow } \\
\text { sample and muscle biopsy }\end{array}$ & N/A & N/A \\
\hline NCT02421484 & $\begin{array}{l}\text { Cellular immunotherapy for septic } \\
\text { shock: A phase } 1 \text { trial (CISS) }\end{array}$ & Completed & $\begin{array}{l}\text { Ottawa Hospital Research } \\
\text { Institute }\end{array}$ & Sepsis & Intravenous & $\begin{array}{l}0.3 \times 10^{6}, 1 \times 10^{6} \text { and } 3 \times 10^{6} \\
\text { cells/kg body weight was } \\
\text { administered to participants }\end{array}$ & $\begin{array}{l}\text { Single dose } \\
\text { of MSCs } \\
\text { demonstrated to } \\
\text { be safe and was } \\
\text { tolerated well. }\end{array}$ & 1 \\
\hline NCT03369275 & $\begin{array}{l}\text { Cellular Immunotherapy for Septic } \\
\text { Shock (CISS2) }\end{array}$ & Not yet recruiting & $\begin{array}{l}\text { Ottawa Hospital Research } \\
\text { Institute }\end{array}$ & $\begin{array}{l}\text { Sepsis, Septic } \\
\text { Shock }\end{array}$ & Intravenous & $\begin{array}{c}\text { Participants will receive } 3 \times 10^{8} \\
\text { BM- HMSCs }\end{array}$ & N/A & 2 \\
\hline NCT01849237 & $\begin{array}{l}\text { Russian clinical trial of mesenchymal } \\
\text { stem cells in patients with septic shock } \\
\text { and severe neutropenia }\end{array}$ & Unknown & $\begin{array}{l}\text { National Research center } \\
\text { for Hematology }\end{array}$ & Sepsis & Intravenous & $\begin{array}{l}\text { Participants will receive } 1-2 \times 10^{6} \\
\text { MSC intravenous infusions up to } \\
10 \mathrm{~h} \text { after septic shock. }\end{array}$ & N/A & $1 \& 2$ \\
\hline NCT02883803 & $\begin{array}{l}\text { Treatment of Severe Infections with } \\
\text { Mesenchymal Stem Cells (CHOCMSC) }\end{array}$ & Not yet recruiting & $\begin{array}{l}\text { Central Hospital Nancy } \\
\text { France }\end{array}$ & Septic Shock & Intravenous & $\begin{array}{l}\text { Participants will receive } 1 \times 10^{6} \\
\text { cells/kg body weight after } 12 \mathrm{~h} \text { of } \\
\text { septic shock }\end{array}$ & N/A & 2 \\
\hline NCT02328612 & $\begin{array}{l}\text { Randomized, Parallel Group, Placebo } \\
\text { Control, Unicentric, Interventional } \\
\text { Study to Assess The Effect of } \\
\text { Expanded Human Allogeneic } \\
\text { Adipose-derived Mesenchymal Adult } \\
\text { Stem Cells on The Human Response to } \\
\text { Lipopolysaccharide in Human } \\
\text { Volunteers (CELLULA) }\end{array}$ & Completed & Tigenix S.A.U & Sepsis & Intravenous & $\begin{array}{l}0.25 \times 10^{6}, 1 \times 10^{6} \text { and } 4 \times 10^{6} \\
\text { cells } / \mathrm{kg} \text { body weight were } \\
\text { administered to different sets } \\
\text { of participants }\end{array}$ & $\begin{array}{l}\text { Intravenous } \\
\text { infusion of } \\
\text { The cells exhibited } \\
\text { anti-inflammatory } \\
\text { effects and } \\
\text { proved to be } \\
\text { safe and efficient }\end{array}$ & 1 \\
\hline
\end{tabular}


Table 3. MSC based therapy clinical trials for COVID-19.

\begin{tabular}{|c|c|c|c|c|c|c|c|c|}
\hline NCT No. & Title & Status & Company Name & Disease/Conditions & Route of Administration & Intervention/Mechanism Target & Results & Phase \\
\hline NCT04333368 & $\begin{array}{l}\text { Cell therapy using } \\
\text { Umbilical cord-derived } \\
\text { Mesenchymal Stromal } \\
\text { Cells in SARS-CoV-2 } \\
\text { related ARDS } \\
\text { (STROMA-CoV2) }\end{array}$ & Recruiting & Hopitaux de Paris & COVID-19 & Intravenous & $\begin{array}{l}\text { Participants will receive } 1 \times 10^{6} \\
\text { UC-MSCs in } 60 \text { min. Via peripheral or } \\
\text { central venous line }\end{array}$ & N/A & 1 and 2 \\
\hline NCT04392778 & $\begin{array}{l}\text { Clinical use of stem } \\
\text { cells for The treatment } \\
\text { of COVID-19 }\end{array}$ & Recruiting & SBÜ & $\begin{array}{l}\text { COVID-19, } \\
\text { Pneumonia, } \\
\text { Multiple Organ } \\
\text { Failure, } \\
\text { CoronaVirus } \\
\text { Infection }\end{array}$ & Intravenous & $\begin{array}{l}\text { Participants will receive } 3 \times 10^{6} \mathrm{MSC} \text { on } \\
\text { Day } 0,3 \text { and } 6 \text {. }\end{array}$ & N/A & 1 and 2 \\
\hline NCT04252118 & $\begin{array}{l}\text { Mesenchymal stem cell } \\
\text { treatment for } \\
\text { pneumonia patients } \\
\text { infected with } \\
\text { COVID-19 }\end{array}$ & Recruiting & Beijing 302 Hospital & COVID-19 & Intravenous & $\begin{array}{l}\text { Participants will receive } 3 \times 10^{7} \text { of MSCs } \\
\text { on day } 0,3 \text { and } 6\end{array}$ & N/A & 1 \\
\hline NCT04348435 & $\begin{array}{l}\text { A randomized, } \\
\text { double-blind, } \\
\text { placebo-controlled } \\
\text { clinical trial to } \\
\text { determine The safety } \\
\text { and efficacy of hope } \\
\text { biosciences allogenic } \\
\text { mesenchymal stem cell } \\
\text { therapy (HB-adMSCs) } \\
\text { to provide protection } \\
\text { against COVID-19 }\end{array}$ & Enrolling by Invitation & Hope biosciences & COVID-19 & Intravenous & $\begin{array}{l}2 \times 10^{8}, 1 \times 10^{8} 0.5 \times 10^{8} \text { and } 0.1 \times 10^{8} \\
\text { Allogenic HB-adMSCs given to } 4 \\
\text { different sets participants on day } 0,2,6 \text {, } \\
10 \text {, and day } 14\end{array}$ & N/A & 2 \\
\hline NCT04366063 & $\begin{array}{l}\text { Mesenchymal Stem cell } \\
\text { Therapy for } \\
\text { SARS-CoV-2 related } \\
\text { Acute Respiratory } \\
\text { Distress Syndrome } \\
\text { Treatment with }\end{array}$ & Recruiting & Royan Institute & COVID-19 & Intravenous & $\begin{array}{l}\text { Participants will receive } 2 \text { doses of } 100 \times \\
10^{6} \text { MSC at day } 0 \text { and } 2 \text { and } 2 \text { doses of } \\
\text { EVs at day } 4 \text { and } 6\end{array}$ & N/A & 2 and 3 \\
\hline NCT04288102 & $\begin{array}{l}\text { mesenchymal system } \\
\text { cells for severe } \\
\text { Coronavirus Disease } \\
2019 \text { (COVID-19) }\end{array}$ & Recruiting & Beijing 302 & COVID-19 & Intravenous & $\begin{array}{l}\text { Participants will receive } 4 \times 10^{7} \text { MSCs } 3 \\
\text { times a day on day } 0,3 \text { and } 6\end{array}$ & $\mathrm{~N} / \mathrm{A}$ & 2 \\
\hline NCT04349631 & $\begin{array}{l}\text { A Clinical Trial to } \\
\text { Determine The safety } \\
\text { and efficacy of Hope } \\
\text { Biosciences Autologous } \\
\text { Mesenchymal Stem Cell } \\
\text { Therapy (HB-adMSCs) } \\
\text { to provide protection } \\
\text { Against COVID-19 }\end{array}$ & Enrolling by Invitation & Hope biosciences & COVID-19 & Intravenous & $\begin{array}{l}\text { Participants will receive } 5 \text { IV infusions } \\
\text { of autologous, AD-MSCs collected and } \\
\text { infused and follow up on week } 6,14,26\end{array}$ & N/A & 2 \\
\hline
\end{tabular}


Table 3. Cont.

\begin{tabular}{|c|c|c|c|c|c|c|c|c|}
\hline NCT04324996 & $\begin{array}{l}\text { A Phase I/II Study of } \\
\text { universal off-the-shelf- } \\
\text { NKG2D-ACE2 } \\
\text { CAR-NK Cells for } \\
\text { Therapy of COVID-19 }\end{array}$ & Recruiting & $\begin{array}{l}\text { Chongqing Public } \\
\text { Health Medical Center }\end{array}$ & COVID-19 & Intravenous & $\begin{array}{l}\text { Participants will receive } 1 \times 10^{8} \text { cells } \\
\text { administered per kilogram of body weight }\end{array}$ & N/A & 1 and 2 \\
\hline NCT04273646 & $\begin{array}{l}\text { Study of Human } \\
\text { Umbilical Cord } \\
\text { Mesenchymal Stem } \\
\text { cells in The treatment of } \\
\text { Severe COVID-19 }\end{array}$ & Not recruiting yet & $\begin{array}{l}\text { Wuhan Union } \\
\text { Hospital China }\end{array}$ & $\begin{array}{l}\text { COVID-19, } 2019 \\
\text { Novel Coronavirus } \\
\text { pneumonia }\end{array}$ & Intravenous & $\begin{array}{l}\text { Participants will receive } 0.5 \times 10^{6} \\
\text { UC-MSCs cells/kg body weight } \\
\text { administered on day 1, day } 3 \text {, day } 5 \text {, } \\
\text { and day } 7\end{array}$ & N/A & N/A \\
\hline NCT04397471 & $\begin{array}{l}\text { A study to collect bone } \\
\text { marrow for process } \\
\text { development and } \\
\text { production of BM-MSC } \\
\text { to treat severe } \\
\text { COVID-19 Pneumonitis } \\
\text { (COMET20d } \\
\text { Treatment of COVID-19 }\end{array}$ & Not recruiting yet & $\begin{array}{l}\text { Cambridge Cellular } \\
\text { Therapies Laboratory }\end{array}$ & $\begin{array}{l}\text { COVID-19, } \\
\text { Pneumonia }\end{array}$ & Donation & $\begin{array}{l}30-80 \mathrm{~mL} \text { sample of bone marrow } \\
\text { collected from posterior superior } \\
\text { iliac crests }\end{array}$ & N/A & N/A \\
\hline NCT04382547 & $\begin{array}{l}\text { Associated Pneumonia } \\
\text { with Allogenic Pooled } \\
\text { Olfactory } \\
\text { Mucosa-derived } \\
\text { Mesenchymal Stem } \\
\text { Cells }\end{array}$ & Enrolling by Invitation & $\begin{array}{l}\text { Institute of Biophysics } \\
\text { and Cell Engineering of } \\
\text { National Academy of } \\
\text { Sciences of Belarus }\end{array}$ & $\begin{array}{l}\text { COVID-19, } \\
\text { Pneumonia }\end{array}$ & Intravenous & $\begin{array}{l}\text { Participants will receive standard } \\
\text { treatments and also allogenic pooled } \\
\text { olfactory mucosa derived MSCs }\end{array}$ & N/A & 1 and 2 \\
\hline NCT04366271 & $\begin{array}{l}\text { Clinical Trial of } \\
\text { Allogenic Mesenchymal } \\
\text { Cells from Umbilical } \\
\text { Cord Tissue with } \\
\text { Patients with } \\
\text { COVID-19 } \\
\text { (MESCEL-COVID-19) }\end{array}$ & Recruiting & $\begin{array}{l}\text { Hospital Infantil } \\
\text { Universitario Nino } \\
\text { Jesus, Madrid Spain }\end{array}$ & COVID-19 & Intravenous & $\begin{array}{l}\text { Participants will receive } 1 \text { infusion of } \\
\text { undifferentiated allogenic UC-MSCs }\end{array}$ & N/A & 2 \\
\hline NCT04361942 & $\begin{array}{l}\text { Treatment of Severe } \\
\text { COVID-19 Pneumonia } \\
\text { with Allogeneic } \\
\text { Mesenchymal Stromal } \\
\text { Cells (COVID_MSV) } \\
\text { (COVID_MSV) }\end{array}$ & Recruiting & Red de Terapia Celular & $\begin{array}{l}\text { COVID-19, } \\
\text { Pneumonia }\end{array}$ & Intravenous & Participants will receive $1 \times 10^{6} \mathrm{MSCs}$ & N/A & 2 \\
\hline NCT04346368 & $\begin{array}{l}\text { Bone Marrow-Derived } \\
\text { Mesenchymal Stem cell } \\
\text { treatment for severe } \\
\text { patients with } \\
\text { coronavirus disease } \\
2019 \text { (COVID-19 }\end{array}$ & Not recruiting yet & $\begin{array}{l}\text { Guangzhou Institute of } \\
\text { Respiratory Disease }\end{array}$ & COVID-19 & Intravenous & $\begin{array}{l}\text { Participants will receive } 1 \times 10^{6} \text { MSCs } \\
\mathrm{kg} / \text { body weight on day } 1\end{array}$ & N/A & 1 and 2 \\
\hline
\end{tabular}


Table 3. Cont

\begin{tabular}{|c|c|c|c|c|c|c|c|c|}
\hline NCT04416139 & $\begin{array}{l}\text { Mesenchymal stem } \\
\text { cells for acute } \\
\text { respiratory distress } \\
\text { Syndrome due to } \\
\text { COVID-19 } \\
\text { Safety and Efficacy }\end{array}$ & Recruiting & $\begin{array}{l}\text { Instituto Nacional de } \\
\text { Ciencias Medicas y } \\
\text { Nutricion Salvador } \\
\text { Zubiran }\end{array}$ & COVID-19 & Intravenous & $\begin{array}{l}\text { Participants will receive a single dose of } \\
1 \times 106 \text { MSCs }\end{array}$ & N/A & 2 \\
\hline NCT04336254 & $\begin{array}{l}\text { Study of Allogenic } \\
\text { Human Dental Pulp } \\
\text { Mesenchymal Stem } \\
\text { Cells to treat severe } \\
\text { COVID-19 Patients }\end{array}$ & Recruiting & $\begin{array}{l}\text { Renmin Hospital of } \\
\text { Wuhan University }\end{array}$ & COVID-19 & Intravenous & $\begin{array}{l}\text { Participants will receive } 3 \times 10^{7} \text { human } \\
\text { dental pulp stem cells on day } 1 \text {, day } 4 \\
\text { and day } 7\end{array}$ & N/A & 1 and 2 \\
\hline NCT04428801 & $\begin{array}{l}\text { Autologous } \\
\text { Adipose-derived Stem } \\
\text { cells (Ad-MSCs) for } \\
\text { COVID-19 }\end{array}$ & Not recruiting yet & $\begin{array}{l}\text { Celltex Therapeutics } \\
\text { Corporation }\end{array}$ & COVID-19 & Intravenous & $\begin{array}{l}\text { Participants will receive } 2 \times 10^{8} \\
\text { Ad-MSCs on day } 0 \text {, day } 3 \text { and day } 6\end{array}$ & N/A & 2 \\
\hline NCT04269525 & $\begin{array}{l}\text { Umbilical Cord } \\
\text { (UC)-Derived } \\
\text { Mesenchymal Stem } \\
\text { Cells (MSCs) Treatment } \\
\text { for The 2019-novel } \\
\text { Coronavirus (nCOV) } \\
\text { Pneumonia }\end{array}$ & Recruiting & $\begin{array}{l}\text { ZhiYong Peng, } \\
\text { Zhongnan Hospital }\end{array}$ & $\begin{array}{l}\text { COVID-19 } \\
\text { Pneumonia }\end{array}$ & Intravenous & $\begin{array}{l}\text { Participants will receive UC-MSC } \\
\text { infusions and day } 1 \text {, day } 3 \text { and day } 5\end{array}$ & N/A & 2 \\
\hline NCT04429763 & $\begin{array}{l}\text { Safety and Efficacy of } \\
\text { Mesenchymal Stem } \\
\text { Cells in } \\
\text { The management of } \\
\text { severe COVID-19 } \\
\text { pneumonia }\end{array}$ & Not recruiting yet & Trustem & COVID-19 & Intravenous & $\begin{array}{l}\text { Participants will receive } 1 \text { dose of } \\
1 \times 10^{6} \text { MSCs }\end{array}$ & N/A & 2 \\
\hline NCT04366323 & $\begin{array}{l}\text { Clinical Trial to Assess } \\
\text { The Safety and Efficacy } \\
\text { of Intravenous } \\
\text { Administration of } \\
\text { Allogeneic Adult } \\
\text { Mesenchymal Stem } \\
\text { Cells of Expanded } \\
\text { Adipose Tissue in } \\
\text { Patients with Severe } \\
\text { Pneumonia Due to } \\
\text { COVID-19 }\end{array}$ & Recruiting & $\begin{array}{l}\text { Andalusian Network } \\
\text { for design and } \\
\text { translation of } \\
\text { Advanced Therapies }\end{array}$ & COVID-19 & Intravenous & $\begin{array}{l}\text { Participants will receive } 8 \times 10^{7} \\
\text { allogenic Ad-MSCs }\end{array}$ & N/A & 1 and 2 \\
\hline NCT04352803 & $\begin{array}{l}\text { Adipose Mesenchymal } \\
\text { cells for Abadement of } \\
\text { SARS-CoV-2 } \\
\text { Respiratory } \\
\text { Compromise in } \\
\text { COVID-19 Disease }\end{array}$ & Not recruiting yet & Regeneris Medical & $\begin{array}{l}\text { COVID-19, } \\
\text { Cytokine Storm }\end{array}$ & Intravenous & $\begin{array}{l}\text { Participants will receive } 0.5 \times 10^{6} \\
\text { autologous ad-MSCs }\end{array}$ & N/A & 1 and 2 \\
\hline
\end{tabular}


Table 3. Cont.

\begin{tabular}{|c|c|c|c|c|c|c|c|c|}
\hline NCT04398303 & $\begin{array}{l}\text { ACT-20 in Patients with } \\
\text { severe COVID-19 } \\
\text { Pneumonia }\end{array}$ & Not recruiting yet & Aspire Health Science & $\begin{array}{l}\text { COVID-19 } \\
\text { Pneumonia }\end{array}$ & Intravenous & $\begin{array}{l}\text { Participants will receive } 1 \times 10^{6} \\
\text { allogenic human umbilical } \\
\text { derived MSCs }\end{array}$ & $\mathrm{N} / \mathrm{A}$ & 2 \\
\hline NCT04339660 & $\begin{array}{l}\text { Clinical Research of } \\
\text { Human Mesenchymal Stem } \\
\text { Cells in The Treatment of } \\
\text { COVID-19 Pneumonia }\end{array}$ & Recruiting & $\begin{array}{l}\text { Puren Hospital Affliated to } \\
\text { Wuhan University of Science } \\
\text { and Technology }\end{array}$ & COVID-19 & Intravenous & $\begin{array}{l}\text { Participants will receive } 1 \times 10^{6} \text { per } \\
\mathrm{kg} / \text { bodyweight UC-MSCs }\end{array}$ & N/A & 1 \\
\hline NCT04444271 & $\begin{array}{l}\text { Mesenchymal Stem Cell } \\
\text { Infusion for } \\
\text { COVID-19 Infection }\end{array}$ & Recruiting & Armed Forces Bone Marrow & COVID-19 & Intravenous & $\begin{array}{l}\text { Participants will receive } 1 \times 10^{6} \text { cells } / \mathrm{kg} \\
\text { body weight of MSCs }\end{array}$ & N/A & 1 and 2 \\
\hline 2020-001682-36 & $\begin{array}{l}\text { Double-blind, } \\
\text { placebo-controlled phase } \\
\text { I/II clinical trial to evaluate } \\
\text { The safety and efficacy of } \\
\text { allogeneic mesenchymal } \\
\text { stem cells (MSV }{ }^{\circledR} \text {-allo) in } \\
\text { acute respiratory failure in } \\
\text { patients with COVID-19 } \\
\text { pneumonia. }\end{array}$ & Ongoing & CITOSPIN S.L. & COVID-19 & Intravenous & $\begin{array}{l}\text { Adult allogeneic stem cell mesenchymal } \\
\text { stem cells expanded in suspension }\end{array}$ & N/A & 1 \\
\hline NCT0444520 & $\begin{array}{l}\text { A Study of Cell Therapy in } \\
\text { COVID-19 Subjects with } \\
\text { Acute Kidney Injury Who } \\
\text { Are Receiving Renal } \\
\text { Replacement Therapy } \\
\text { Treatment of Coronavirus }\end{array}$ & Not recruiting yet & Sentien Biotechnologies, Inc. & COVID-19 & Integration & $\begin{array}{l}\text { Allogenic SB-101 biologic } \\
\text { combination device }\end{array}$ & N/A & 1 \\
\hline NCT04461925 & $\begin{array}{l}\text { COVID-19 Pneumonia } \\
\text { (Pathogen SARS-CoV-2) } \\
\text { With Cryopreserved } \\
\text { Allogeneic P_MMSCs and } \\
\text { UC-MMSCs }\end{array}$ & Recruiting & Institute of Cell Therapy & $\begin{array}{l}\text { COVID-19 and } \\
\text { Pneumonia }\end{array}$ & Intravenous & $\begin{array}{l}\text { Participants will receive } 1 \times 10^{6} \text { cells } / \mathrm{kg} \\
\text { body weight } 3 \text { times a day on day } 1,4 \\
\text { and } 7\end{array}$ & N/A & 1 and 2 \\
\hline NCT04445454 & $\begin{array}{l}\text { Mesenchymal Stromal Cell } \\
\text { Therapy for Severe } \\
\text { Covid-19 Infection } \\
\text { Efficacy of Intravenous }\end{array}$ & Recruiting & University of Liege & COVID-19 & Intravenous & $\begin{array}{l}\text { Participants will receive } 3 \text { doses of } \\
\text { (1.5)-3.0 } \times 10^{6} / \mathrm{BM} \text {-MSC } \mathrm{kg} / \text { body weight } \\
\text { at } 3-4 \text { days interval }\end{array}$ & N/A & 1 and 2 \\
\hline NCT04437823 & $\begin{array}{l}\text { Infusions of Stem Cells in } \\
\text { The Treatment of } \\
\text { COVID-19 Patients }\end{array}$ & Recruiting & Jinnah Hospital & COVID-19 & Intravenous & $\begin{array}{l}\text { Participants will receive } 5 \times 10^{5} \text { of } \\
\text { UC-MSCs on day } 1,3 \text { and } 5\end{array}$ & N/A & 2 \\
\hline NCT04456361 & $\begin{array}{l}\text { Use of Mesenchymal Stem } \\
\text { Cells in Acute Respiratory } \\
\text { Distress Syndrome Caused } \\
\text { by COVID-19 }\end{array}$ & $\begin{array}{l}\text { Active, not } \\
\text { recruiting }\end{array}$ & $\begin{array}{l}\text { Instituto de Medicina } \\
\text { Regenerativa }\end{array}$ & COVID-19 & Intravenous & $\begin{array}{l}\text { Participants will receive } 1 \times 10^{8} \text { of } \\
\text { Wharton jelly derived UC-MSCs }\end{array}$ & $\mathrm{N} / \mathrm{A}$ & 2 \\
\hline
\end{tabular}


Table 3. Cont

\begin{tabular}{|c|c|c|c|c|c|c|c|c|}
\hline NCT04457609 & $\begin{array}{l}\text { Administration of Allogenic } \\
\text { UC-MSCs as Adjuvant } \\
\text { Therapy for Critically Ill } \\
\text { COVID-19 Patients }\end{array}$ & Recruiting & $\begin{array}{l}\text { Indonesia } \\
\text { University }\end{array}$ & COVID-19 & Intravenous & $\begin{array}{l}\text { Participants will 1st receive } \\
\text { standardized treatment oseltamivir and } \\
\text { azithromycin and then } 1 \times 10^{6} \\
\text { UC-MSCs in } 100 \mathrm{cc} \text { of } 0.9 \% \mathrm{NaCl} \text { in } 1 \mathrm{~h}\end{array}$ & N/A & 2 and 3 \\
\hline NCT04467047 & $\begin{array}{l}\text { Safety and Feasibility of } \\
\text { Allogenic MSC in } \\
\text { The Treatment of } \\
\text { COVID-19 (COVID19) }\end{array}$ & Not recruiting yet & $\begin{array}{l}\text { Hospital de Clinicas } \\
\text { de Porto Alegre }\end{array}$ & COVID-19 & Intravenous & Participants will receive $1 \times 10^{6} \mathrm{MSCs}$ & N/A & 1 \\
\hline NCT04466098 & $\begin{array}{l}\text { Multiple Dosing of } \\
\text { Mesenchymal Stromal Cells in } \\
\text { Patients with ARDS } \\
\text { (COVID-19) }\end{array}$ & Not recruiting yet & $\begin{array}{l}\text { Masonic Cancer } \\
\text { Center, University } \\
\text { of Minnesota }\end{array}$ & COVID-19 & Intravenous & $\begin{array}{l}\text { Participants will receive a thawed } \\
\text { product consisting of } 300 \times 10^{6} \text { in } \\
\text { DMSO in } 1: \mathrm{w} / \text { Dextran } 40+5 \% \text { human } \\
\text { serum albumin }\end{array}$ & N/A & 2 \\
\hline NCT04486001 & $\begin{array}{l}\text { Study of Intravenous } \\
\text { Administration of Allogeneic } \\
\text { Adipose Stem Cells for } \\
\text { COVID-19 (CoronaStem1) } \\
\text { Umbilical Cord Tissue (UC) }\end{array}$ & Not recruiting yet & $\begin{array}{l}\text { Personalized Stem } \\
\text { Cells, Inc. }\end{array}$ & COVD-19 & Intravenous & $\begin{array}{l}\text { Participants will receive adipose derived } \\
\text { stem cells }\end{array}$ & N/A & 1 \\
\hline NCT04490486 & $\begin{array}{l}\text { Derived Mesenchymal Stem } \\
\text { Cells (MSC) Versus Placebo to } \\
\text { Treat Acute Pulmonary } \\
\text { Inflammation Due to } \\
\text { COVID-19 (COVID-19) }\end{array}$ & Not recruiting yet & Joshua M Hare & COVID-19 & Intravenous & $\begin{array}{l}\text { Participants will receive } 1 \times 10^{8} \\
\text { UC-MSCS on day } 0 \text { and day } 3\end{array}$ & N/A & 1 \\
\hline NCT04456439 & $\begin{array}{l}\text { Intermediate-size Expanded } \\
\text { Access Program (EAP), } \\
\text { Mesenchymal Stromal Cells } \\
\text { (MSC) for Multisystem } \\
\text { Inflammatory Syndrome in } \\
\text { Children (MIS-C) Associated } \\
\text { with Coronavirus Disease } \\
\text { (COVID-19) }\end{array}$ & Available & $\begin{array}{l}\text { Mesoblast } \\
\text { International Sàrl }\end{array}$ & COVID-19 & Intravenous & $\begin{array}{l}\text { Participants will receive } 2 \times 10^{6} \\
\text { remestemcel-L within a 5-day period }\end{array}$ & N/A & N/A \\
\hline NCT04313322 & $\begin{array}{l}\text { Treatment of COVID-19 } \\
\text { Patients using Wharton Jelly } \\
\text { Mesenchymal Stem Cells }\end{array}$ & Recruiting & Stem Cells Arabia & COVID-19 & Intravenous & $\begin{array}{l}\text { Participants will receive WJ-MSCs } \\
\text { suspended in } 25 \mathrm{~mL} \text { of saline solution }\end{array}$ & N/A & 1 \\
\hline NCT04371601 & $\begin{array}{l}\text { Safety and effectiveness of } \\
\text { mesenchymal stem cells in } \\
\text { The treatment of pneumonia of } \\
\text { coronavirus disease } 2019\end{array}$ & Active, Not recruiting & $\begin{array}{l}\text { Fuzhou General } \\
\text { Hospital }\end{array}$ & $\begin{array}{l}\text { COVID-19 } \\
\text { Pneumonia }\end{array}$ & Intravenous & $\begin{array}{l}\text { Participants will first receive standard } \\
\text { treatment (oseltamivir and hormones) } \\
\text { followed by } 1 \text { dose of } 1 \times 10^{6} \text { cells } \\
\mathrm{kg} / \text { body weight once daily for } 4 \text { days }\end{array}$ & N/A & 1 \\
\hline NCT04362189 & $\begin{array}{l}\text { Efficacy and Safety of } \\
\text { Allogenic HB-adMSCs for } \\
\text { The treatment of COVID-19 }\end{array}$ & Recruiting & Hope biosciences & COVID-19 & Intravenous & $\begin{array}{l}\text { Participants will receive } 1 \times 10^{8} \text { of } \\
\text { HB-adMSCs on day } 0,3,7 \text { and } 10\end{array}$ & $\mathrm{~N} / \mathrm{A}$ & 2 \\
\hline NCT04384445 & $\begin{array}{l}\text { Organicell Flow for Patients } \\
\text { With COVID-19 }\end{array}$ & Not yet recruiting & $\begin{array}{l}\text { Organicell } \\
\text { Regenerative } \\
\text { Medicine }\end{array}$ & COVID-19 & Intravenous & $\begin{array}{l}\text { Participants will receive } 1 \mathrm{~mL} \text { of } \\
\text { organicell flow on days } 0,4 \text {, and } 8\end{array}$ & $\mathrm{~N} / \mathrm{a}$ & 1 and 2 \\
\hline
\end{tabular}


Table 3. Cont.

\begin{tabular}{|c|c|c|c|c|c|c|c|c|}
\hline NCT04341610 & $\begin{array}{l}\text { ASC Therapy for } \\
\text { Patients with Severe } \\
\text { Respiratory COVID-19 } \\
\text { (ASC COVID-19) }\end{array}$ & $\begin{array}{l}\text { Withdrawn (Not } \\
\text { approved by ethical } \\
\text { committee) }\end{array}$ & $\begin{array}{l}\text { Rigshospitalet, } \\
\text { Denmark }\end{array}$ & $\begin{array}{l}\text { Respiratory tract } \\
\text { diseases } \\
\text { (COVID-19) }\end{array}$ & Intravenous & $\begin{array}{l}100 \text { million allogenic adipose-derived } \\
\text { mesenchymal stem cells in } 100 \mathrm{~mL} \text { saline }\end{array}$ & N/A & 1 and 2 \\
\hline NCT04293692 & $\begin{array}{l}\text { Therapy for Pneumonia } \\
\text { Patients Infected by } \\
2019 \text { Novel } \\
\text { Coronavirus }\end{array}$ & $\begin{array}{l}\text { Withdrawn (Patients } \\
\text { were transferred to } \\
\text { designated hospitals for } \\
\text { treatment as needed, } \\
\text { The clinical trials } \\
\text { cannot be conducted.) }\end{array}$ & $\begin{array}{l}\text { Puren Hospital } \\
\text { Affiliated to Wuhan } \\
\text { University of } \\
\text { Science and } \\
\text { Technology }\end{array}$ & COVID & Intravenous & $\begin{array}{l}0.5 \times 10^{6} \text { UC-MSCs } \mathrm{kg} / \text { body weight } \\
\text { suspended in } 100 \mathrm{~mL} \text { saline on day } 1 \text {, } \\
\text { day } 3 \text {, day } 5 \text { and day } 7\end{array}$ & $\mathrm{~N} / \mathrm{A}$ & N/A \\
\hline
\end{tabular}

$\mathrm{N} / \mathrm{A}=$ Not yet available. 


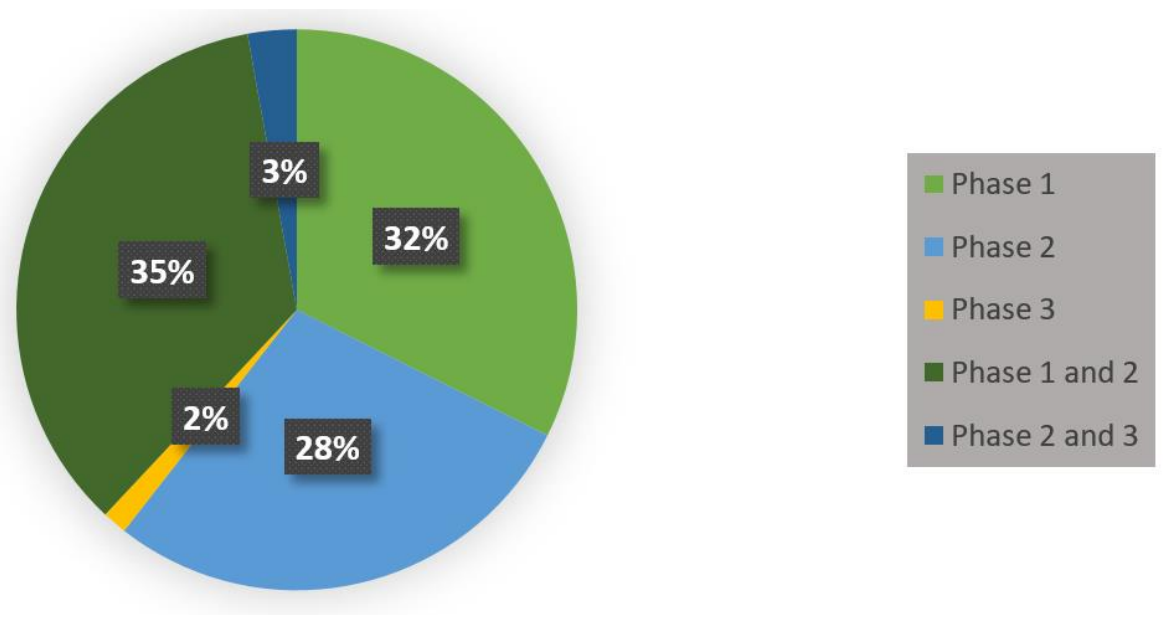

Figure 6. COVID-19, ARDS and sepsis MSC-based therapy-related clinical trials in phase 1, phase 1 and 2 , phase 2 , phase 2 and 3 , and phase 3 .

The majority of MSC-related clinical trials for ARDS are currently still in phase one and are focused on demonstrating The safety of intravenous administration of MSCs (see Table 1). In a clinical trial conducted by Wilson et al., human-derived BM-MSCs were not only safely administered to patients intravenously but also were tolerated well. Wilson et al. have since proceeded to phase 2, but The findings and outcomes have yet to be published [78]. Similarly, a clinical trial conducted by The University of California by Matthay et al. demonstrated The safety of one dose of MSCs to patients with severe ARDS. However, The viability of MSCs had to be improved [71]. To date, no clinical trials are using aerosolized MSCs. Therefore, future research should concentrate on The safety and efficacy of aerosolized MSCs, EVs, and MSC-CM, and examine their potential in a clinical setting.

Similar to cellular therapy-related clinical trials for ARDS, most cellular therapy-related trials for sepsis are currently in phase one demonstrating The safety and tolerability of MSC administration (see Table 2). In 2017, a published clinical trial by McIntyre et al. aimed to demonstrate The safety of administrating one dose of allogenic MSC to participants. They found that The infusion of 1 dose of MSCs "seemed" safe [143]. In a clinical trial conducted by Perlee et al., adipose-derived MSCs were intravenously administered to a human endotoxemia model. They (AD-MSCs) were well tolerated. The AD-MSCs also demonstrated time-dependent pro-inflammatory and anti-inflammatory effects [144]. However, several cellular therapy-related clinical trials have been deemed unsuccessful, even though many preclinical trials that administer MSCs to mice have been demonstrated to modulate inflammation, repair tissue, and enhance pathogen clearance, and which collectively can reduce mortality rate.

One significant obstacle to therapy presented by these diseases is The associated cytokine storm. Leng et al. have suggested The potential use of MSCs in mitigating its effects and to this end, have conducted an early phase 7 patient study. In that study, after only three weeks of MSC transplantation, patients' C plasma levels had dropped significantly [145]. Cao et al. reported that The cytokine storm levels in patients in The ICU had activated immune cells that led to inhibited function of endothelial cells, capillary leakage, and mucous block in The lung and respiratory failure. The administration of MSC led to a decrease in inflammation in severe patients in The ICU, which implies that The use of MSCs helped ICU patients with severe manifestations of coronavirus into recovery $[87,145]$. Similar to Leng et al., Guo et al. treated 30 patients with UC-MSCs. No adverse effects were observed or attributable from transplantation. However, this study demonstrated The paracrine factors that are known to be secreted by MSCs resulted in The modulation and downregulation of The cytokine storm and assisted in The restoration of oxygenation levels. This suggests that UC-MSCs could improve The lung environment and function and The modulation of pro-inflammatory cytokines [146]. In a study performed by Ercelen et al., MSCs were transplanted into patients suffering 
from severe COVID-19. They demonstrated that two clinically severe patients did not require intubation after transplantation. Not only were adverse effects not observed but also all patients were discarded from The ICU 1-2 weeks after transplantation. One patient had died from complications not related to transplantation [147]. In a similar study conducted by Sengupta et al., patients were administered The bone marrow-derived exosome product 'ExoFlo' intravenously. They demonstrated The reversal of hypoxia, immune reconstitution and, again, The downregulation of The cytokine storm [105]. Collectively these studies prove that MSCs, MSC-CM, and exosomes are a definite asset treating COVID-19 in a clinical setting.

One critical issue is that The appropriate dose for administration has not yet been established. From The present clinical trials, The dosages range from $0.5 \times 10^{6}$ cells $\mathrm{kg} / \mathrm{body}$ weight to $1 \times 10^{8}$ cells $\mathrm{kg} / \mathrm{body}$ weight. In addition, The vast majority of these clinical trials administer cells intravenously, which could result in a thrombogenic deposition if not cautious [148]. A limited number of clinical trials have demonstrated exosomes' ability to reduce lung inflammation and pathological impairment that stem from various types of lung injury. Intravenous administration of exosomes may result in aggregation or clumping in The injured microcirculation, and there is a higher risk of mutagenicity and oncogenicity. This issue does not arise when using nebulizers, specifically nebulized MSCs-Exo [149]. Previously, this review discussed The use of aerosolized MSCs due to their ability to target The lungs in ways intravenous administration is unable to. Aerosol MSC-based therapy is a novel strategy that is capable of enhancing reparative and regenerative processes in both chronic and acute lung injuries [149]. Researchers and biomedical disciplines are beginning to investigate The tolerance of aerosol inhalation of mesenchymal stem cell exosomes (see Table 4). 
Table 4. Aerosol and aerosolized cell therapy clinical trials.

\begin{tabular}{|c|c|c|c|c|c|c|c|c|}
\hline NCT No. & Title & Status & Company Name & Disease/Conditions & Route of Administration & Intervention/Mechanism Target & Results & Phase \\
\hline NCT04313647 & $\begin{array}{l}\text { A Tolerance Clinical } \\
\text { Study on Aerosol } \\
\text { Inhalation of } \\
\text { Mesenchymal Stem } \\
\text { Cells Exosomes in } \\
\text { Healthy Volunteers } \\
\text { Study Evaluating }\end{array}$ & Recruiting & Ruijin Hospital & $\begin{array}{c}\text { Safety and } \\
\text { Tolerance }\end{array}$ & Inhalation & $\begin{array}{c}2 \times 10^{8}, 4 \times 10^{8}, 8 \times 10^{8}, 16 \times 10^{8}, \\
20 \times 10^{8} \text { nano vesicles } / 3 \mathrm{~mL} \text { to be } \\
\text { administered to different sets } \\
\text { of participants }\end{array}$ & N/A & 1 \\
\hline NCT04473170 & $\begin{array}{c}\text { The Safety and Efficacy } \\
\text { of Autologous } \\
\text { Non-Hematopoietic } \\
\text { Peripheral Blood Stem } \\
\text { Cells in COVID-19 } \\
\text { (SENTAD-COVID) }\end{array}$ & Completed & $\begin{array}{l}\text { Abu Dhabi Stem } \\
\text { Cells Center }\end{array}$ & COVID-19 & Inhalation & $\begin{array}{l}\text { Participants were put into groups; } \\
\text { group A received NHPBSC } \\
\text { through jet nebulization and group } \\
\text { B received standard care }\end{array}$ & N/A & 1 and 2 \\
\hline NCT04389385 & $\begin{array}{l}\text { COVID-19 Specific T } \\
\text { cell-derived Exosomes } \\
\text { (CSTC-Exo) }\end{array}$ & $\begin{array}{l}\text { Active, Not } \\
\text { recruiting yet }\end{array}$ & $\begin{array}{l}\text { TC Erciyes } \\
\text { University }\end{array}$ & COVID-19 & Inhalation & $\begin{array}{l}\text { Participants will receive specific T } \\
\text { cell-derived exosomes (CSTC-Exo) } \\
\text { Aerosol inhalation of CSTC-Exo } \\
(2.0 \times 108 \text { nanovesicles } / 3 \mathrm{~mL} \text { at } \\
\text { Day } 1,2,3,4 \text { and } 5 \text { times daily }\end{array}$ & N/A & 1 \\
\hline NCT04491240 & $\begin{array}{l}\text { Evaluation of Safety } \\
\text { and Efficiency of } \\
\text { Method of Exosome } \\
\text { Inhalation in } \\
\text { SARS-CoV-2 Associated } \\
\text { Pneumonia } \\
\text { (COVID-19EXO) }\end{array}$ & $\begin{array}{l}\text { Enrolling by } \\
\text { Invitation }\end{array}$ & $\begin{array}{l}\text { State-Financed } \\
\text { Health Facility } \\
\text { "Samara Regional } \\
\text { Medical Center } \\
\text { Dinasty" }\end{array}$ & COVID-19 & Inhalation & $\begin{array}{c}2 \text { sets of participants will receive } \\
0.5-2 \times 10^{10} \text { of } \\
\text { nanoparticles (exosomes) }\end{array}$ & N/A & 1 and 2 \\
\hline NCT04276987 & $\begin{array}{l}\text { A pilot clinical study on } \\
\text { inhalation of } \\
\text { mesenchymal stem } \\
\text { cells exosomes } \\
\text { treating severe } \\
\text { novel coronavirus }\end{array}$ & Not recruiting yet & Ruijin Hospital & COVID-19 & Inhalation & $\begin{array}{c}\text { Participants will receive } \\
\text { MSC-derived exosomes } 5 \text { times, } \\
\text { aerosol inhalations of } \\
\text { MSC-derived exosomes }\left(2.0 \times 10^{8}\right. \\
\text { nano vesicles/3 mL at Days } 1,2,3 \text {, } \\
\quad 4 \text { and } 5)\end{array}$ & N/A & 1 \\
\hline
\end{tabular}




\section{Conclusions}

The primary objective of this review was to shed light on The potential benefits of MSC-based therapies for respiratory and pulmonary diseases and infections and The potential benefits of aerosolized and nebulized MSC-based therapies. Cell-based therapies, notably MSC-based therapies, are at The forefront of treatment of lung diseases due to their anti-inflammatory, regenerative, and immunomodulatory properties. The pleiotropic effects of MSCs and their potential to be enhanced by preconditioning and potentiation methods make them a promising form of therapy. However, preconditioning will have to be established prior to being used clinically. In addition, due to The possibilities of tumor and emboli formation that can result from The administration of MSCs, The EVs, exosomes and MSC secretome may be a better option. Despite The issues that revolve around MSC, they could be an optimum solution in treating various and complex pathologies of lung diseases.

The need for more efficient administration routes is clearly supported by The studies discussed throughout this paper. Even while proven successful in many cases, there are several critical issues that revolve around The use of IV administration that can be avoided using inhalation, aerosolization, or nebulization technology. Studies suggest that aerosolized MSCs, EVs, and MSC-CM can deliver cells directly to The site of injury. Aerosolization maintains high efficacy and high distribution of cells in The lung and also a minimized risk of cell loss and morphological changes that may occur when administered via intravenous, intratracheal, and intranasal administration. They have also demonstrated their capability to be faster acting than other various routes. However, extensive research should be carried out on various cell therapies and their compatibility with different nebulizers before this strategy can be used in a clinical setting.

Finally, for these therapies to become available commercially, they will need to undergo regulatory approval processes, very likely in combination with specific delivery devices for reliable and reproducible dosing. A recent review covers this area in greater detail, and discusses The likely US and EU regulatory frameworks for The ATMP/delivery device combinations [150].

Author Contributions: Conceptualization, R.M.; writing-original draft preparation, H.B.; writing-review and editing, H.B. and R.M. All authors have read and agreed to The published version of the manuscript.

Funding: This research received no external funding.

Conflicts of Interest: Ronan MacLoughlin is an employee of Aerogen Limited. Hosanna Brave declares no conflicts of interest.

\section{References}

1. European Medicines. Advanced Therapy Medicinal Products: Overview. 2017. Available online: https: //www.ema.europa.eu/en/human-regulatory/overview/advanced-therapy-medicinal-products-overview (accessed on 20 May 2020).

2. Rousseau, C.F.; Maciulaitis, R.; Śladowski, D.; Narayanan, G. Cell and Gene Therapies: European View on Challenges in Translation and How to Address Them. Front. Med. 2018, 5, 158. [CrossRef] [PubMed]

3. Hartmann-Fritsch, F.; Marino, D.; Reichmann, E. About ATMPs, SOPs and GMP: The Hurdles to Produce Novel Skin Grafts for Clinical Use. Transfus. Med. Hemotherapy 2016, 43, 344-352. [CrossRef] [PubMed]

4. Hanna, E.; Rémuzat, C.; Auquier, P.; Toumi, M. Advanced therapy medicinal products: Current and future perspectives. J. Mark. Access Health Policy 2016, 4, 301. [CrossRef] [PubMed]

5. Ham, R.M.T.; Hoekman, J.; Hövels, A.M.; Broekmans, A.W.; Leufkens, H.G.; Klungel, O.H. Challenges in Advanced Therapy Medicinal Product Development: A Survey among Companies in Europe. Mol. Ther. Methods Clin. Dev. 2018, 11, 121-130. [CrossRef] [PubMed]

6. Seoane-Vazquez, E.; Shukla, V.; Rodriguez-Monguio, R. Innovation and competition in advanced therapy medicinal products. EMBO Mol. Med. 2019, 11, 9992. [CrossRef]

7. Iglesias-López, C.; Agustí, A.; Obach, M.; Vallano, A. Regulatory Framework for Advanced Therapy Medicinal Products in Europe and United States. Front. Pharmacol. 2019, 10, 921. [CrossRef] 
8. Gilead. U.S. FDA Approves Kite's Tecartus ${ }^{\mathrm{TM}}$, The First and Only CAR T Treatment for Relapsed or Refractory Mantle Cell Lymphoma. Available online: https:/www.gilead.com/news-and-press/press-room/ press-releases/2020/7/us-fda-approves-kites-tecartus-the-first-and-only-car-t-treatment-for-relapsed-orrefractory-mantle-cell-lymphoma (accessed on 13 August 2020).

9. European Medicines. EU/3/19/2220. Available online: https://www.ema.europa.eu/en/medicines/human/ orphan-designations/eu3192220 (accessed on 13 August 2020).

10. Tuch, B. Stem cells-A clinical update. Aust. Fam. Physician 2006, 35, 719.

11. O'Brien, T.E.; Barry, F.P. Stem Cell Therapy and Regenerative Medicine. Mayo Clin. Proc. 2009, 84, 859-861. [CrossRef] [PubMed]

12. Hui, H.-X.; Tang, Y.; Hu, M.; Zhao, X. Stem Cells: General Features and Characteristics. In Stem Cells in Clinic and Research; IntechOpen: London, UK, 2011; pp. 3-20.

13. Barfoot, J.; Bruce, D.; Laurie, G.; Bauer, N.; Paterson, J.; Bownes, M. Stem Cell: Science and Ethics, Stemcell—Resourse, 3rd ed.; BBSRC: Edinburgh, UK, 2016; pp. 1-56.

14. Lo, B.; Parham, L. Ethical issues in stem cell research. Endocr. Rev. 2009, 30, 204-213. [CrossRef] [PubMed]

15. Chagastelles, P.C.; Nardi, N.B. Biology of stem cells: An overview. Kidney Int. Suppl. 2011, 1, $63-67$. [CrossRef] [PubMed]

16. Abreu, S.C.; Antunes, M.A.; Pelosi, P.; Morales, M.M.; Rocco, P.R.M. Mechanisms of cellular therapy in respiratory diseases. Intensive Care Med. 2011, 37, 1421-1431. [CrossRef] [PubMed]

17. Horie, S.; Kavanagh, B.P.; Laffey, J. What's new in cell therapies in ARDS? Intensive Care Med. 2015, 42, 779-782. [CrossRef] [PubMed]

18. Li, Z.; Jiang, C.-M.; An, S.; Cheng, Q.; Huang, Y.-F.; Wang, Y.-T.; Gou, Y.; Xiao, L.; Yu, W.-J.; Wang, J. Immunomodulatory properties of dental tissue-derived mesenchymal stem cells. Oral Dis. 2013, 20, 25-34. [CrossRef] [PubMed]

19. Deans, R.J.; Moseley, A.B. Mesenchymal stem cells: Biology and potential clinical uses. Exp. Hematol. 2000, 28, 875-884. [CrossRef]

20. Dominici, M.; Le Blanc, K.; Mueller, I.; Slaper-Cortenbach, I.; Marini, F.; Krause, D.; Deans, R.; Keating, A.; Prockop, D.; Horwitz, E. Minimal criteria for defining multipotent mesenchymal stromal cells. The International Society for Cellular Therapy position statement. Cytotherapy 2006, 8, 315-317. [CrossRef]

21. Hmadcha, A.; Martin-Montalvo, A.; Gauthier, B.R.; Soria, B.; Capilla-González, V. Therapeutic Potential of Mesenchymal Stem Cells for Cancer Therapy. Front. Bioeng. Biotechnol. 2020, 8, 43. [CrossRef]

22. Maumus, M.; Jorgensen, C.; Noel, D. Mesenchymal stem cells in regenerative medicine applied to rheumatic diseases: Role of secretome and exosomes. Biochimie 2013, 95, 2229-2234. [CrossRef]

23. Silva, L.H.A.; Antunes, M.A.; Dos Santos, C.C.; Weiss, D.J.; Cruz, F.F.; Rocco, P.R.M. Strategies to improve The therapeutic effects of mesenchymal stromal cells in respiratory diseases. Stem Cell Res. Ther. 2018, 9, 1-9. [CrossRef]

24. Iannaccone, G.; Scacciavillani, R.; Del Buono, M.G.; Camilli, M.; Ronco, C.; Lavie, C.J.; Abbate, A.; Crea, F.; Massetti, M.; Aspromonte, N. Weathering The Cytokine Storm in COVID-19: Therapeutic Implications. CardioRenal Med. 2020, 21,1-11. [CrossRef]

25. Pankajakshan, D.; Agrawal, D.K. Mesenchymal Stem Cell Paracrine Factors in Vascular Repair and Regeneration. J. Biomed. Technol. Res. 2014, 1, 1-9. [CrossRef]

26. Lee, J.W.; Fang, X.; Krasnodembskaya, A.D.; Howard, J.P.; Matthay, M.A. Concise Review: Mesenchymal Stem Cells for Acute Lung Injury: Role of Paracrine Soluble Factors. Stem Cells 2011, 29, 913-919. [CrossRef] [PubMed]

27. Lee, J.H.; Han, Y.-S.; Lee, S.H. Potentiation of biological effects of mesenchymal stem cells in ischemic conditions by melatonin via upregulation of cellular prion protein expression. J. Pineal Res. 2017, 62, 12385. [CrossRef] [PubMed]

28. Hu, C.; Li, L. Preconditioning influences mesenchymal stem cell properties in vitro and in vivo. J. Cell Mol. Med. 2018, 22, 1428-1442. [CrossRef] [PubMed]

29. Saini, U.; Gumina, R.J.; Wolfe, B.; Kuppusamy, M.L.; Kuppusamy, P.; Boudoulas, K.D. Preconditioning mesenchymal stem cells with caspase inhibition and hyperoxia prior to hypoxia exposure increases cell proliferation. J. Cell Biochem. 2013, 114, 2612-2623. [CrossRef] [PubMed] 
30. Gao, F.; Hu, X.-Y.; Xie, X.-J.; Xu, Q.-Y.; Wang, Y.-P.; Liu, X.-B.; Xiang, M.-X.; Wang, Y.S.; Wang, J.-A. Heat shock protein 90 protects rat mesenchymal stem cells against hypoxia and serum deprivation-induced apoptosis via The PI3K/Akt and ERK1/2 pathways. J. Zhejiang Univ. Sci. B 2010, 11, 608-617. [CrossRef] [PubMed]

31. Saparov, A.; Ogay, V.; Nurgozhin, T.; Jumabay, M.; Chen, C.-W. Preconditioning of Human Mesenchymal Stem Cells to Enhance Their Regulation of The Immune Response. Stem Cells Int. 2016, 2016, 1-10. [CrossRef]

32. Gutierrez, T.M.; Silva, J.D.; Cruz, F.F.; Alegria, S.; Xisto, D.G.; Assis, E.F.; Castro-Faria-Neto, H.C.; Dos Santos, C.C.; Morales, M.M.; Rocco, P.R.M. Insult-dependent effect of bone marrow cell therapy on inflammatory response in a murine model of extrapulmonary acute respiratory distress syndrome. Stem Cell Res. Ther. 2013, 4, 123. [CrossRef]

33. Jiang, C.; Liu, J.; Zhao, J.; Xiao, L.; An, S.; Gou, Y.; Quan, H.; Cheng, Q.; Zhang, Y.-L.; He, W.; et al. Effects of Hypoxia on The Immunomodulatory Properties of Human Gingiva-Derived Mesenchymal Stem Cells. J. Dent. Res. 2014, 94, 69-77. [CrossRef]

34. Liu, Y.-Y.; Chiang, C.-H.; Hung, S.-C.; Chian, C.-F.; Tsai, C.-L.; Chen, W.-C.; Zhang, H. Hypoxia-preconditioned mesenchymal stem cells ameliorate ischemia/reperfusion-induced lung injury. PLoS ONE 2017, 12, 0187637. [CrossRef]

35. Sagaradze, G.; Grigorieva, O.; Nimiritsky, P.; Basalova, N.; Kalinina, N.; Akopyan, Z.; Efimenko, A. Conditioned Medium from Human Mesenchymal Stromal Cells: Towards The Clinical Translation. Int. J. Mol. Sci. 2019, 20, 1656. [CrossRef]

36. Osugi, M.; Katagiri, W.; Yoshimi, R.; Inukai, T.; Hibi, H.; Ueda, M. Conditioned Media from Mesenchymal Stem Cells Enhanced Bone Regeneration in Rat Calvarial Bone Defects. Tissue Eng. Part A 2012, 18, 1479-1489. [CrossRef] [PubMed]

37. Hwang, B.; Liles, W.C.; Waworuntu, R.; Mulligan, M.S. Pretreatment with bone marrow-derived mesenchymal stromal cell-conditioned media confers pulmonary ischemic tolerance. J. Thorac. Cardiovasc. Surg. 2016, 151, 841-849. [CrossRef] [PubMed]

38. Kim, S.-Y.; Lee, J.-H.; Kim, H.J.; Park, M.K.; Huh, J.W.; Ro, J.Y.; Oh, Y.-M.; Lee, S.-D.; Lee, Y.-S. Mesenchymal stem cell-conditioned media recovers lung fibroblasts from cigarette smoke-induced damage. Am. J. Physiol. Cell Mol. Physiol. 2012, 302, 891-908. [CrossRef] [PubMed]

39. Shologu, N.; Scully, M.; Laffey, J.; O’Toole, D. Human Mesenchymal Stem Cell Secretome from Bone Marrow or Adipose-Derived Tissue Sources for Treatment of Hypoxia-Induced Pulmonary Epithelial Injury. Int. J. Mol. Sci. 2018, 19, 2996. [CrossRef] [PubMed]

40. Eleuteri, S.; Fierabracci, A. Insights into The Secretome of Mesenchymal Stem Cells and Its Potential Applications. Int. J. Mol. Sci. 2019, 20, 4597. [CrossRef] [PubMed]

41. Vizoso, F.J.; Eiró, N.; Cid, S.; Schneider, J.; Perez-Fernandez, R. Mesenchymal Stem Cell Secretome: Toward Cell-Free Therapeutic Strategies in Regenerative Medicine. Int. J. Mol. Sci. 2017, 18, 1852. [CrossRef] [PubMed]

42. Ranganath, S.H.; Levy, O.; Inamdar, M.S.; Karp, J.M. Harnessing The Mesenchymal Stem Cell Secretome for The Treatment of Cardiovascular Disease. Cell Stem Cell 2012, 10, 244-258. [CrossRef] [PubMed]

43. Barreca, M.M.; Cancemi, P.; Geraci, F. Mesenchymal and Induced Pluripotent Stem Cells-Derived Extracellular Vesicles: The New Frontier for Regenerative Medicine? Cells 2020, 9, 1163. [CrossRef]

44. Monsel, A.; Zhu, Y.-G.; Gudapati, V.; Lim, H.; Lee, J.W. Mesenchymal stem cell derived secretome and extracellular vesicles for acute lung injury and other inflammatory lung diseases. Expert Opin. Boil. Ther. 2016, 16, 859-871. [CrossRef]

45. Bari, E.; Ferrarotti, I.; Saracino, L.; Perteghella, S.; Torre, M.L.; Corsico, A. Mesenchymal Stromal Cell Secretome for Severe COVID-19 Infections: Premises for The Therapeutic Use. Cells 2020, 9, 924. [CrossRef] [PubMed]

46. Akers, J.C.; Gonda, D.; Kim, R.; Carter, B.S.; Chen, C.C. Biogenesis of extracellular vesicles (EV): Exosomes, microvesicles, retrovirus-like vesicles, and apoptotic bodies. J. Neuro-Oncol. 2013, 113, 1-11. [CrossRef] [PubMed]

47. Gangadaran, P.; Ahn, B.-C. Extracellular Vesicle- and Extracellular Vesicle Mimetics-Based Drug Delivery Systems: New Perspectives, Challenges, and Clinical Developments. Pharmaceutical 2020, 12, 442. [CrossRef] [PubMed] 
48. Bari, E.; Ferrarotti, I.; Torre, M.L.; Corsico, A.G.; Perteghella, S. Mesenchymal stem/stromal cell secretome for lung regeneration: The long way through "pharmaceuticalization" for The best formulation. J. Control Release 2019, 309, 11-24. [CrossRef] [PubMed]

49. Ferreira, J.R.; Teixeira, G.Q.; Santos, S.G.; Barbosa, M.A.; Almeida-Porada, G.; Gonçalves, R. Mesenchymal Stromal Cell Secretome: Influencing Therapeutic Potential by Cellular Pre-conditioning. Front. Immunol. 2018, 9, 2837. [CrossRef] [PubMed]

50. Han, C.; Sun, X.; Liu, L.; Jiang, H.; Shen, Y.; Xu, X.; Li, J.; Zhang, G.; Huang, J.; Lin, Z.; et al. Exosomes and Their Therapeutic Potentials of Stem Cells. Stem Cells Int. 2016, 2016, 1-11. [CrossRef]

51. Kishore, R.; Khan, M. More than tiny sacks: Stem cell exosomes as cell-free modality for cardiac repair. Circ. Res. 2016, 118, 330-343. [CrossRef]

52. Vakhshiteh, F.; Atyabi, F.; Ostad, S.N. Mesenchymal stem cell exosomes: A two-edged sword in cancer therapy. Int. J. Nanomed. 2019, 14, 2847-2859. [CrossRef]

53. Lai, R.C.; Yeo, R.W.Y.; Lim, S.K. Mesenchymal Stem Cell Exosomes, in Seminars in Cell E Developmental Biology; Elsevier: Amsterdam, The Netherlands, 2015; Volume 40, pp. 82-88.

54. Kordelas, L.; Rebmann, V.; Ludwig, A.-K.; Radtke, S.; Ruesing, J.; Doeppner, T.R.; Epple, M.; Horn, P.A.; Beelen, D.W.; Giebel, B. MSC-derived exosomes: A novel tool to treat therapy-refractory graft-versus-host disease. Leukemia 2014, 28, 970-973. [CrossRef]

55. Kim, I. A brief overview of cell therapy and its product. J. Korean Assoc. Oral Maxillofac. Surg. 2013, 39, 201-202. [CrossRef]

56. Dodson, B.P.; Levine, A.D. Challenges in The translation and commercialization of cell therapies. BMC Biotechnol. 2015, 15, 70. [CrossRef]

57. Bartel, R.L. Stem Cells and Cell Therapy. In Translational Regenerative Medicine; Elsevier: Amsterdam, The Netherlands, 2015; pp. 107-112.

58. Meij, P.; Canals, J.M.; Lowery, M.; Scott, M. Advanced Therapy Medicinal Products. In Proceedings of The 2019 PDA Europe Conference on Advanced Therapy Medicinal Products (ATMPs), Vilnius, Lithuania, 4-5 June 2019.

59. Arrighi, N. Stem Cells: Therapeutic Innovations Under Control; Elsevier: Amsterdam, The Netherlands, 2018.

60. Kazmi, B.; Inglefield, C.J.; Lewis, M.P. Autologous cell therapy: Current treatments and future prospects. Wounds 2009, 21, 234-242. [PubMed]

61. Gage, F.H. "Cell therapy”, Nature, Research Support, Non-U S Gov't Research Support, U S Gov't. PHS Rev. 1998, 392, 18-24.

62. Tögel, F.; Cohen, A.; Zhang, P.; Yang, Y.; Hu, Z.; Westenfelder, C. Autologous and Allogeneic Marrow Stromal Cells Are Safe and Effective for The Treatment of Acute Kidney Injury. Stem Cells Dev. 2009, 18, 475-486. [CrossRef] [PubMed]

63. Lukomska, B.; Stanaszek, L.; Zuba-Surma, E.; Łęgosz, P.; Sarzyńska, S.; Drela, K. Challenges and Controversies in Human Mesenchymal Stem Cell Therapy. Stem Cells Int. 2019, 2019, 9628536. [CrossRef] [PubMed]

64. Rezoagli, E.; Murphy, E.J.; Laffey, J.; O’Toole, D. The Safety and Efficiency of Addressing ARDS Using Stem Cell Therapies in Clinical Trials. In Stem Cell-Based Therapy for Lung Disease; Springer Science and Business Media LLC: Berlin/Heidelberg, Germany, 2019; pp. 219-238.

65. Zhang, J.; Huang, X.; Wang, H.; Liu, X.; Zhang, T.; Wang, Y.; Hu, D. The challenges and promises of allogeneic mesenchymal stem cells for use as a cell-based therapy. Stem Cell Res. Ther. 2015, 6, 234. [CrossRef]

66. Tan, Y.; Ooi, S.; Wang, L. Immunogenicity and Tumorigenicity of Pluripotent Stem Cells and their Derivatives: Genetic and Epigenetic Perspectives. Curr. Stem Cell Res. Ther. 2014, 9, 63-72. [CrossRef]

67. Mason, R.; Broaddus, V.C.; Martin, T.; King, T.; Schraufnagel, D.; Murray, J.; Nadel, J. Murray and Nadel's Textbook of Respiratory Medicine E-Book: 2-Volume Set; Elsevier Health Sciences: Amsterdam, The Netherlands, 2010.

68. Schraufnagel, D.E. Breathing in America: Diseases, Progress, and Hope; American Thoracic Society: New York, NY, USA, 2010.

69. Griffiths, M.J.D.; McAuley, D.F.; Perkins, G.D.; Barrett, N.; Blackwood, B.; Boyle, A.; Chee, N.; Connolly, B.; Dark, P.; Finney, S.J.; et al. Guidelines on The management of acute respiratory distress syndrome. BMJ Open Respir. Res. 2019, 6, 420. [CrossRef]

70. Rawal, G.; Yadav, S.; Kumar, R. Acute Respiratory Distress Syndrome: An Update and Review. J. Transl. Int. Med. 2018, 6, 74-77. [CrossRef]

71. Matthay, M.A. The Acute Respiratory Distress Syndrome. N. Engl. J. Med. 1996, 334, 1469-1470. [CrossRef] 
72. Bhatia, M.; Moochhala, S. Role of inflammatory mediators in The pathophysiology of acute respiratory distress syndrome. J. Pathol. 2004, 202, 145-156. [CrossRef]

73. Leaver, S.K.; Evans, T.W. Acute respiratory distress syndrome. BMJ 2007, 335, 389-394. [CrossRef] [PubMed]

74. Luh, S.-P.; Chiang, C. Acute lung injury/acute respiratory distress syndrome (ALI/ARDS): The mechanism, present strategies and future perspectives of therapies. J. Zhejiang Univ. Sci. B 2007, 8, 60-69. [CrossRef] [PubMed]

75. Pierrakos, C.; Karanikolas, M.; Scolletta, S.; Karamouzos, V.; Velissaris, D. Acute Respiratory Distress Syndrome: Pathophysiology and Therapeutic Options. J. Clin. Med. Res. 2012, 4, 7-16. [CrossRef] [PubMed]

76. Esteve, F.; Lopez-Delgado, J.C.; Javierre, C.; Skaltsa, K.; Carrio, M.L.L.; Rodríguez-Castro, D.; Torrado, H.; Farrero, E.; Diaz-Prieto, A.; Ventura, J.L.L.; et al. Evaluation of The $\mathrm{PaO}_{2} / \mathrm{FiO}_{2}$ ratio after cardiac surgery as a predictor of outcome during hospital stay. BMC Anesthesiol. 2014, 14, 83. [CrossRef] [PubMed]

77. Dai, Q.; Wang, S.; Liu, R.; Wang, H.; Zheng, J.; Yu, K. Risk factors for outcomes of acute respiratory distress syndrome patients: A retrospective study. J. Thorac. Dis. 2019, 11, 673-685. [CrossRef]

78. Wilson, J.G.; Liu, K.D.; Zhuo, H.; Caballero, L.; McMillan, M.; Fang, X.; Cosgrove, K.; Vojnik, R.; Calfee, C.S.; Lee, J.-W.; et al. Mesenchymal stem (stromal) cells for treatment of ARDS: A phase 1 clinical trial. Lancet Respir. Med. 2015, 3, 24-32. [CrossRef]

79. De Hemptinne, Q.; Remmelink, M.; Brimioulle, S.; Salmon, I.; Vincent, J.-L. ARDS: A clinicopathological confrontation. Chest 2009, 135, 944-949. [CrossRef]

80. Polat, G.; Ugan, R.A.; Cadirci, E.; Halici, Z. Sepsis and Septic Shock: Current Treatment Strategies and New Approaches. Eurasian J. Med. 2017, 49, 53-58. [CrossRef]

81. U.o.B. Columbia. Sepsis Leading Cause of Death Worldwide. Faculty of Medicine. Available online: https://www.med.ubc.ca/news/sepsis-leading-cause-of-death-worldwide/ (accessed on 8 May 2020).

82. Hajj, J.; Blaine, N.; Salavaci, J.; Jacoby, D.S. The "Centrality of Sepsis": A Review on Incidence, Mortality, and Cost of Care. Health 2018, 6, 90. [CrossRef]

83. Kim, W.-Y.; Hong, S.-B. Sepsis and Acute Respiratory Distress Syndrome: Recent Update. Tuberc. Respir. Dis. 2016, 79, 53-57. [CrossRef]

84. Hostiuc, S.; Dermengiu, D.; Ceausu, M.; Rusu, M.C.; Curca, G.C. Pathology and immunopathology of The lung in sepsis. Rom. J. Leg. Med. 2011, 19, 83-88. [CrossRef]

85. Keane, C.; Jerkic, M.; Laffey, J. Stem Cell-based Therapies for Sepsis. Anesthesiology 2017, 127, $1017-1034$. [CrossRef] [PubMed]

86. Kim, W.-K.; Jung, H.; Kim, D.-H.; Kim, E.-Y.; Chung, J.-W.; Cho, Y.-S.; Park, S.G.; Park, B.-C.; Ko, Y.; Bae, K.-H.; et al. Regulation of adipogenic differentiation by LAR tyrosine phosphatase in human mesenchymal stem cells and 3T3-L1 preadipocytes. J. Cell Sci. 2009, 122, 4160-4167. [CrossRef] [PubMed]

87. Huang, C.; Wang, Y.; Li, X.; Ren, L.; Zhao, J.; Hu, Y.; Cheng, Z. Clinical features of patients infected with 2019 novel coronavirus in Wuhan, China. Lancet 2020, 395, 497-506. [CrossRef]

88. Raj, K.; Rohit; Ghosh, A.; Singh, S. Coronavirus as silent killer: Recent advancement to pathogenesis, therapeutic strategy and future perspectives. VirusDisease 2020, 1, 1-9. [CrossRef]

89. Weiss, D.J. Stem cells, cell therapies, and bioengineering in lung biology and diseases. Comprehensive review of The recent literature 2010-2012. Ann. Am. Thorac. Soc. 2013, 10, 45-97. [CrossRef]

90. Lamas, C.C.; De Lorenzo, A.R. COVID-19 and The cardiovascular system. Heart Vessel. Transplant. $2020,4,37$. [CrossRef]

91. Zu, Z.Y.; Di Jiang, M.; Xu, P.P.; Chen, W.; Ni, Q.Q.; Lu, G.M.; Zhang, L.J. Coronavirus Disease 2019 (COVID-19): A Perspective from China. Radiologia 2020, 296, 15-25. [CrossRef]

92. CDC COVID-19 Response Team; Bialek, S.; Boundy, E.; Bowen, V.; Chow, N.; Cohn, A.; Dowling, N.; Ellington, S.; Gierke, R.; Hall, A.; et al. Severe Outcomes Among Patients with Coronavirus Disease 2019 (COVID-19)—United States, February 12-16 March, 2020. MMWR. Morb. Mortal. Wkly. Rep. 2020, 69, 343-346. [CrossRef]

93. Mungroo, M.R.; Khan, N.A.; Siddiqui, R. Novel Coronavirus: Current Understanding of Clinical Features, Diagnosis, Pathogenesis, and Treatment Options. Pathogens 2020, 9, 297. [CrossRef]

94. Chow, N.; Fleming-Dutra, K.; Gierke, R.; Hall, A.; Hughes, M.; Pilishvili, T.; Ritchey, M.; Roguski, K.; Skoff, T.; Ussery, E. Preliminary estimates of The prevalence of selected underlying health conditions among patients with coronavirus disease 2019-United States, February 12-March 28, 2020. MMWR. Morb. Mortal. Wkly. Rep. 2020, 69, 382-386. [CrossRef] 
95. Hoang, V.T.; Dao, T.L.; Gautret, P. Recurrence of positive SARS-CoV-2 in patients recovered from COVID-19. Published ahead of print. J. Med. Virol. 2020. [CrossRef] [PubMed]

96. Jordan, R.E.; Adab, P.; Cheng, K.K. Covid-19: Risk factors for severe disease and death. BMJ 2020, 368, m1198. [CrossRef] [PubMed]

97. Conti, P.; Ronconi, G.; Caraffa, A.; Gallenga, C.; Ross, R.; Frydas, I.; Kritas, S. Induction of proinflammatory cytokines (IL-1 and IL-6) and lung inflammation by Coronavirus-19 (COVI-19 or SARS-CoV-2): Anti-inflammatory strategies. J. Biol. Regul. Homeost. Agents 2020, 34, 1. [PubMed]

98. Medicine, J.H. What Coronavirus Does to The Lungs. Available online: https://www.hopkinsmedicine.org/ health/conditions-and-diseases/coronavirus/what-coronavirus-does-to-the-lungs (accessed on 20 July 2020).

99. Susan, R.W. Coronavirus Pathogenesis and The Emerging Pathogen Severe Acute Respiratory Syndrome Coronavirus/Susan R. Weiss, Sonia Navas-Martin. Microbiol. Mol. Biol. Rev. 2005, 69, 635-664.

100. Coperchini, F.; Chiovato, L.; Croce, L.; Magri, F.; Rotondi, M. The cytokine storm in COVID-19: An overview of The involvement of The chemokine/chemokine-receptor system. Cytokine Growth Factor Rev. 2020, 53, 25-32. [CrossRef]

101. Mason, R.J. Pathogenesis of COVID-19 from a cell biologic perspective. Eur. Respir. J. 2020, 55, 2000607. [CrossRef]

102. Zhang, C.; Wu, Z.; Li, J.-W.; Zhao, H.; Wang, G.-Q. The cytokine release syndrome (CRS) of severe COVID-19 and Interleukin-6 receptor (IL-6R) antagonist Tocilizumab may be The key to reduce The mortality. Int. J. Antimicrob. Agents 2020, 55, 105954. [CrossRef]

103. Barton, L.M.; Duval, E.J.; Stroberg, E.; Ghosh, S.; Mukhopadhyay, S. COVID-19 Autopsies, Oklahoma, USA. Am. J. Clin. Pathol. 2020, 153, 725-733. [CrossRef]

104. Rajarshi, K.; Chatterjee, A.; Ray, S. Combating COVID-19 with mesenchymal stem cell therapy. Biotechnol. Rep. 2020, 26, e00467. [CrossRef]

105. Sengupta, V.; Sengupta, S.; Lazo, J.A.; Woods, P.; Nolan, A.; Bremer, N. Exosomes Derived from Bone Marrow Mesenchymal Stem Cells as Treatment for Severe COVID-19. Stem Cells Dev. 2020, 29, 747-754. [CrossRef] [PubMed]

106. Halpin, D.M.G.; Singh, D.; Hadfield, R.M. Inhaled corticosteroids and COVID-19: A systematic review and clinical perspective. Eur. Respir. J. 2020, 55, 2001009. [CrossRef] [PubMed]

107. Bourne, D. PHAR 7633, Routes of Drug Administration, 7th ed.; Boomer Press: Aurora, CO, USA, 2014; pp. 1-14.

108. Zhou, Q.; Jin, J.-F.; Zhu, L.-L.; Chen, M.; Xu, H.-M.; Wang, H.-F.; Feng, X.-Q.; Zhu, X.-P. The optimal choice of medication administration route regarding intravenous, intramuscular, and subcutaneous injection. Patient Prefer. Adherence 2015, 9, 923-942. [CrossRef] [PubMed]

109. Wei, Y.; Zhao, L. Passive lung-targeted drug delivery systemsviaintravenous administration. Pharm. Dev. Technol. 2013, 19, 129-136. [CrossRef] [PubMed]

110. Eggenhofer, E.; Benseler, V.; Kroemer, A.; Popp, F.C.; Geissler, E.; Schlitt, H.J.; Baan, C.C.; Dahlke, M.H.; Hoogduijn, M.J. Mesenchymal stem cells are short-lived and do not migrate beyond The lungs after intravenous infusion. Front. Immunol. 2012, 3, 297. [CrossRef]

111. Klepikov, I. The Effect of Intravenous Infusion on The Dynamics of Acute Pneumonia. EC Pulmonol. Respir. Med. 2017, 4, 15-20.

112. Osier, M.; Oberdörster, G. Intratracheal inhalation vs intratracheal instillation: Differences in particle effects. Fundam. Appl. Toxicol. 1997, 40, 220-227. [CrossRef]

113. Baran, K. Toxicity Testing, Inhalation. Encycl. Toxicol. 2014, 4, 669-672.

114. Xisto, D.G.; Abreu, S.C.; Antunes, M.A.; Crossetti, J.; Capelozzi, V.L.; Morales, M.M.; Rocco, P.R.M. Intratracheal Versus Intravenous Bone Marrow Mononuclear Cell Therapy in Experimental Chronic Allergic Asthma: Which Is The Best Administration Route? In Proceedings of The American Thoracic Society 2011 International Conference, Denver, CO, USA, 13-18 May 2011; American Thoracic Society: New York, NY, USA, 2011; p. 3588.

115. Garcia-Contreras, L.; Ibrahim, M.; Verma, R. Inhalation drug delivery devices: Technology update. Med. Devices Évid. Res. 2015, 8, 131-139. [CrossRef]

116. Hickey, A.J. Back to The Future: Inhaled Drug Products. J. Pharm. Sci. 2013, 102, 1165-1172. [CrossRef]

117. Pöschl, U. Atmospheric Aerosols: Composition, Transformation, Climate and Health Effects. Angew. Chem. Int. Ed. 2005, 44, 7520-7540. [CrossRef] [PubMed]

118. Ari, A. Aerosol Therapy in Pulmonary Critical Care. Respir. Care 2015, 60, 858-879. [CrossRef] [PubMed] 
119. Tashkin, D. A review of nebulized drug delivery in COPD. Int. J. Chronic Obstr. Pulm. Dis. 2016, 11, 2585-2596. [CrossRef] [PubMed]

120. Gregory, K.L.; Wilken, L.; Hart, M.K. Pulmonary Disease Aerosol Delivery Devices 2017. Available online: https://www.aarc.org/wp-content/uploads/2018/01/aerosol-guide-for-hcp-3rd.pdf (accessed on 1 July 2020).

121. Chandel, A.; Goyal, A.K.; Ghosh, G.; Rath, G. Recent advances in aerosolised drug delivery. Biomed. Pharmacother. 2019, 112, 108601. [CrossRef] [PubMed]

122. Alexander, K. Dosage Forms and Their Routes of Administration; Elsevier BV: Amsterdam, The Netherlands, 2009; pp. 9-29.

123. Stein, S.W.; Thiel, C.G. The History of Therapeutic Aerosols: A Chronological Review. J. Aerosol Med. Pulm. Drug Deliv. 2016, 30, 20-41. [CrossRef]

124. Horie, S.; Masterson, C.; Devaney, J.; Laffey, J. Stem cell therapy for acute respiratory distress syndrome. Curr. Opin. Crit. Care 2016, 22, 14-20. [CrossRef]

125. Gupta, N.; Su, X.; Popov, B.; Lee, J.W.; Serikov, V.; Matthay, M.A. Intrapulmonary Delivery of Bone Marrow-Derived Mesenchymal Stem Cells Improves Survival and Attenuates Endotoxin-Induced Acute Lung Injury in Mice. J. Immunol. 2007, 179, 1855-1863. [CrossRef]

126. Cardenes, N.; Aranda-Valderrama, P.; Carney, J.P.; Torres, J.S.; Alvarez, D.; Kocydirim, E.; Smith, J.A.W.; Ting, A.E.; Lagazzi, L.; Yu, Z.; et al. Cell therapy for ARDS: Efficacy of endobronchial versus intravenous administration and biodistribution of MAPCs in a large animal model. BMJ Open Respir. Res. 2019, 6, e000308. [CrossRef]

127. Ionescu, L.; Byrne, R.N.; Van Haaften, T.; Vadivel, A.; Alphonse, R.S.; Rey-Parra, G.J.; Weissmann, G.; Hall, A.; Eaton, F.; Thébaud, B. Stem cell conditioned medium improves acute lung injury in mice: In vivo evidence for stem cell paracrine action. Am. J. Physiol. Cell. Mol. Physiol. 2012, 303, L967-L977. [CrossRef]

128. Su, V.Y.-F.; Lin, C.-S.; Hung, S.-C.; Yang, K.-Y. Mesenchymal Stem Cell-Conditioned Medium Induces Neutrophil Apoptosis Associated with Inhibition of The NF-кB Pathway in Endotoxin-Induced Acute Lung Injury. Int. J. Mol. Sci. 2019, 20, 2208. [CrossRef]

129. Gotts, J.E.; Matthay, M.A. Cell-based Therapy in Sepsis. A Step Closer. Am. J. Respir. Crit. Care Med. 2018, 197, 280-281. [CrossRef] [PubMed]

130. Kingsley, S.M.K.; Bhat, V. Could stem cells be The future therapy for sepsis? Blood Rev. 2016, 30, 439-452. [CrossRef] [PubMed]

131. Gurudutta, G.; Satija, N.K.; Singh, V.K.; Verma, Y.K.; Gupta, P.; Tripathi, R. Stem cell therapy: A novel \& futuristic treatment modality for disaster injuries. Indian J. Med. Res. 2012, 135, 15-25. [CrossRef] [PubMed]

132. Gonzalez-Rey, E.; Anderson, P.; González, M.A.; Rico, L.; Büscher, D.; Delgado, M. Human adult stem cells derived from adipose tissue protect against experimental colitis and sepsis. Gut 2009, 58, 929-939. [CrossRef] [PubMed]

133. Weil, B.R.; Markel, T.A.; Herrmann, J.L.; Abarbanell, A.M.; Kelly, M.L.; Meldrum, D.R. Stem Cells in Sepsis. Ann. Surg. 2009, 250, 19-27. [CrossRef]

134. Horak, J.; Nalos, L.; Martinkova, V.; Tegl, V.; Vistejnova, L.; Kuncova, J.; Kohoutova, M.; Jarkovska, D.; Dolejsova, M.; Benes, J.; et al. Evaluation of Mesenchymal Stem Cell Therapy for Sepsis: A Randomized Controlled Porcine Study. Front. Immunol. 2020, 11, 126. [CrossRef] [PubMed]

135. Laroye, C.; Lemarié, J.; Boufenzer, A.; Labroca, P.; Cunat, L.; Alauzet, C.; Groubatch, F.; Cailac, C.; Jolly, L.; Bensoussan, D.; et al. Clinical-grade mesenchymal stem cells derived from umbilical cord improve septic shock in pigs. Intensive Care Med. Exp. 2018, 6, 24. [CrossRef]

136. Abreu, S.C.; Xisto, D.G.; De Oliveira, T.B.; Blanco, N.G.; De Castro, L.L.; Kitoko, J.Z.; Olsen, P.C.; Lopes-Pacheco, M.; Morales, M.M.; Weiss, D.J.; et al. Serum from Asthmatic Mice Potentiates The Therapeutic Effects of Mesenchymal Stromal Cells in Experimental Allergic Asthma. Stem Cells Transl. Med. 2018, 8, 301-312. [CrossRef]

137. Kardia, E.; Halim, N.S.S.A.; Yahaya, B.H. Aerosol-Based Cell Therapy for Treatment of Lung Diseases. In Advanced Structural Safety Studies; Springer Science and Business Media LLC: Berlin/Heidelberg, Germany, 2016; Volume 1516, pp. 243-255.

138. Halim, N.S.S.; Ch'Ng, E.S.; Kardia, E.; Ali, S.A.; Radzi, R.; Yahaya, B.H. Aerosolised Mesenchymal Stem Cells Expressing Angiopoietin-1 Enhances Airway Repair. Stem Cell Rev. Rep. 2018, 15, 112-125. [CrossRef] 
139. Averyanov, A.; Konoplyannikov, A.; Zabozlaev, F.; Danilevskaya, O.; Konoplyannikov, M.; Kuzovlev, O.; Koroleva, I. Comparative effects of inhaled and intravenous mesenchymal stem cells in bleomycin-induced pulmonary fibrosis in rabbits. Eur Respir. Soc. 2013, 44, 4-14.

140. Alhasan, L.; Qi, A.; Rezk, A.R.; Yeo, L.Y.; Chan, P.P.Y. Assessment of The potential of a high frequency acoustomicrofluidic nebulisation platform for inhaled stem cell therapy. Integr. Biophys. 2016, 8, 12-20. [CrossRef] [PubMed]

141. McCarthy, S.D.; Horgan, E.; Ali, A.; Masterson, C.; Laffey, J.G.; MacLoughlin, R.; O’Toole, D. Nebulized Mesenchymal Stem Cell Derived Conditioned Medium Retains Antibacterial Properties Against Clinical Pathogen Isolates. J. Aerosol Med. Pulm. Drug Deliv. 2019, 33, 140-152. [CrossRef] [PubMed]

142. Averyanov, A.V.; Konoplyannikov, A.G.; Antonov, N.S.; Osipova, G.L.; Vasil'Eva, O.S.; Sakharova, M.G.; Tatarskii, A.R.; Kobylyansky, V.I. Survival of Mesenchymal Stem Cells in Different Methods of Nebulization. Bull. Exp. Boil. Med. 2018, 164, 576-578. [CrossRef] [PubMed]

143. McIntyre, L.; Watpool, I.; Schlosser, K.; Stewart, D.J.; Mei, S.H.J.; Courtman, D.W.; Granton, J.; Marshall, J.C.; Dos Santos, C.C.; Walley, K.R.; et al. Cellular Immunotherapy for Septic Shock. A Phase I Clinical Trial. Am. J. Respir. Crit. Care Med. 2018, 197, 337-347. [CrossRef] [PubMed]

144. Perlee, D.; Van Vught, L.A.; Scicluna, B.; Maag, A.; Lutter, R.; Kemper, E.M.; Veer, C.V.T.; Punchard, M.A.; González, J.; Richard, M.P.; et al. Intravenous Infusion of Human Adipose Mesenchymal Stem Cells Modifies The Host Response to Lipopolysaccharide in Humans: A Randomized, Single-Blind, Parallel Group, Placebo Controlled Trial. Stem Cells 2018, 36, 1778-1788. [CrossRef] [PubMed]

145. Leng, Z.; Zhu, R.; Hou, W.; Fengchun, Z.; Yangyang, Z.; Luchan, D.; Shan, G.; Meng, F.; Du, D.; Wang, S.; et al. Transplantation of ACE2- Mesenchymal Stem Cells Improves The Outcome of Patients with COVID-19 Pneumonia. Aging Dis. 2020, 11, 216-228. [CrossRef] [PubMed]

146. Guo, Z.; Chen, Y.; Luo, X.; He, X.; Zhang, Y.; Wang, J. Administration of umbilical cord mesenchymal stem cells in patients with severe COVID-19 pneumonia. Crit. Care 2020, 24, 1-3. [CrossRef]

147. Ercelen, N.O.; Bilgili, B.; Monteleone, B.; Gul, F.; Gulay, G.R.; Alpaydin, N.; Demir, O.T.; Simsek, M.; Turan, D.; Karadeniz, O.; et al. MSC Transplantation in Eight Severe COVID-19 Patients: Can Cytokine StormBe Reversed? J. Stem Cell Res. Ther. 2020, 10, 3. [CrossRef]

148. Antebi, B.; Mohammadipoor, A.; Batchinsky, A.I.; Cancio, L.C. The promise of mesenchymal stem cell therapy for acute respiratory distress syndrome. J. Trauma Acute Care Surg. 2018, 84, 183-191. [CrossRef]

149. Polverino, F. Best of Milan 2017-Repair of The emphysematous lung: Mesenchymal stromal cell and matrix. J. Thorac. Dis. 2017, 9, S1544-S1547. [CrossRef]

150. Woods, N.; MacLoughlin, R. Defining a Regulatory Strategy for ATMP/Aerosol Delivery Device Combinations in The Treatment of Respiratory Disease. Pharmaceutics 2020. under review. 